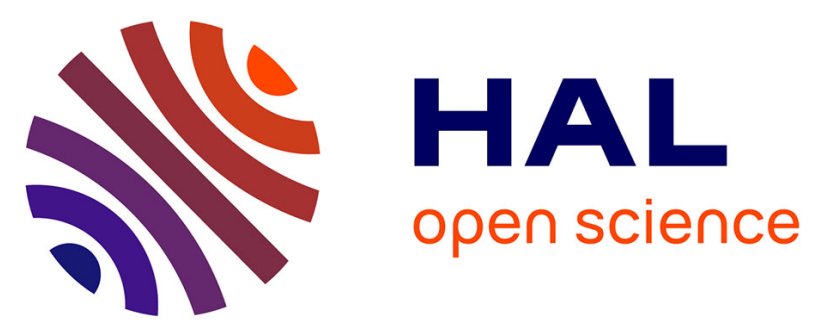

\title{
Molecular characterization and phylogeography of Mediterranean picarels (Spicara flexuosa, S. maena and S. smaris) along the coasts of Turkey and the Eastern Mediterranean
}

Asli Şalcioglu, Chrysoula Gubili, Grigorios Krey, Serdar Sakinan, Raşit Bilgin

\section{To cite this version:}

Asli Şalcioglu, Chrysoula Gubili, Grigorios Krey, Serdar Sakinan, Raşit Bilgin. Molecular characterization and phylogeography of Mediterranean picarels (Spicara flexuosa, S. maena and S. smaris) along the coasts of Turkey and the Eastern Mediterranean. Regional Studies in Marine Science, 2021, 101836, pp.101836. 10.1016/j.rsma.2021.101836 . hal-03293249

\author{
HAL Id: hal-03293249 \\ https://hal.science/hal-03293249
}

Submitted on 20 Jul 2021

HAL is a multi-disciplinary open access archive for the deposit and dissemination of scientific research documents, whether they are published or not. The documents may come from teaching and research institutions in France or abroad, or from public or private research centers.
L'archive ouverte pluridisciplinaire HAL, est destinée au dépôt et à la diffusion de documents scientifiques de niveau recherche, publiés ou non, émanant des établissements d'enseignement et de recherche français ou étrangers, des laboratoires publics ou privés. 
Molecular characterization and phylogeography of Mediterranean picarels (Spicara flexuosa, S. maena and S. smaris) along the coasts of Turkey and the Eastern Mediterranean

\author{
ASLI ŞALCIOĞLU ${ }^{1 *}$, CHRYSOULA GUBILI ${ }^{2}$, GRIGORIOS KREY ${ }^{2}$, \\ SERDAR SAKINAN ${ }^{3}$, RAȘITT BILGIIN ${ }^{1}$ \\ ${ }^{1}$ Institute of Environmental Sciences, Boğaziçi University, Bebek-Istanbul, Turkey. \\ ${ }^{2}$ Hellenic Agricultural Organization-DEMETER, Fisheries Research Institute, Nea \\ Peramos, Kavala, 64007, Greece. \\ ${ }^{3}$ Wageningen Marine Research, IJmuiden, The Netherlands.
}

Corresponding author

*email: asli.salcioglu@gmail.com 


\section{ABSTRACT}

2

3 In this study, molecular taxonomy associated with Spicara flexuosa, Spicara maena,

4 and Spicara smaris was examined with a geographical focus along the coasts of the

5 Turkey and the Mediterranean. In addition, the effects of the Turkish Straits System on

6 the evolutionary history and phylogeography of Spicara flexuosa were investigated.

7 The mitochondrial cytochrome c oxidase I, cytochrome $b$, and the nuclear

8 Interphotoreceptor retinoid-binding protein genes were used for these purposes. Our

9 results indicated that the distinction of the three taxa under Spicara is possible with the two different mitochondrial DNA markers. Nuclear DNA analyses indicated that reproductive isolation of the $S$. maena and $S$. flexuosa was complete. Demographic analyses support the sudden population growth of $S$. flexuosa after a potential bottleneck. The result of the dating analyses suggested that the three Spicara species were differentiated during the early or middle Pliocene. An absence of genetic structure between Spicara flexuosa subpopulations from Turkey indicated the connectivity, within sampling locations, suggesting that the Turkish Straits System is a corridor for gene flow for this species. As picarel populations have experienced rapid decline in their distribution areas in recent years, separate population studies are necessary to help make informed conservation and management decisions for S. maena and S. flexuosa. 20 22 Key words: Eastern Mediterranean; molecular taxonomy; phylogeography; sister species; Turkish Straits Systems. 


\section{INTRODUCTION}

Accurate species identification is the main step in monitoring biodiversity, which is critical for taxonomic identification and conservation efforts (Tillett et al., 2012). In the marine environment, fish species identification based on only external morphological characters can be hard due to morphological similarities among sister species (Chiba et al., 2009; Teletchea, 2009). Such identification problems may have negative impact on fisheries management (Vecchione et al., 2000) and important implications for the conservation of exploited populations (Garcia-Vazquez et al., 2012). In this regard, molecular data can be useful in resolving phylogenetic and taxonomic uncertainties between morphologically similar sister fish species (Chiba et al., 2009; Li et al., 2020), and help to alleviate the aforementioned problems.

One of the unresolved questions in fish phylogeny and taxonomy concerns the family Sparidae, consisting of 39 genera, 166 valid species and 260 synonyms (Nelson et al., 2016; Parenti, 2019; Fricke et al., 2020) including the genera, Spicara and Centracanthus. Orrell et al. (2002) and Orrell and Carpenter (2004) showed that currently defined sub-families of Sparidae were not monophyletic and Spicara was a member of Sparidae. In addition, the monophyly of the family Sparidae is not supported (Chiba et al., 2009), primarily because of the uncertainty of the position of its sister family Centracanthidae, which includes the genera Spicara and Centracanthus. The disagreement in the taxonomy is also reflected in the online marine fish databases as well; according to the World Register of Marine Species (WoRMS), the Integrated Taxonomic Information System (ITIS), and the Marine Species Identification Portal, Spicara spp. are currently placed under the Centracanthidae. However, FishBase, 
49 Catalog of Fishes (Fricke et al., 2020) and Encyclopedia of Life (EOL) (https://eol.org)

50

51

52

53

54

55

56

57

58

59

60

61

62

63

64

65

66

67

68

69

70

71

72

73 place the genus Spicara within the Sparidae.

The taxonomic uncertainty within the Sparidae family is largely influenced by their biogeographical and evolutionary history. Previous biogeographical analyses among the Sparidae family members showed that the common ancestor of Sparid clades has undergone adaptive radiation in order to take advantage of various environmental conditions in the Central Tethys Sea during the Early Paloecene (Orrell and Carpenter, 2004; Chiba et al., 2009). At that time, diversification of the clades occurred simultaneously, and as a result many species evolved and were distributed worldwide in a short time period, as observed for other fish species, such as some coral reef fish (Rocha et al., 2007; 2008) and cichlids (Sugawara et al., 2002). This feature is reflected in the northeastern Atlantic and the Mediterranean distribution of the Sparidae family members, as 24 fish species of this family were reported along these coasts (Bauchot and Hureau, 1986). Adaptive radiation and evolutionary plasticity of many morphological characters could be the main underlying reason behind the morphological similarities and difficulties in the identification of Sparid species (Chiba et al., 2009).

Difficulties in morphological discrimination also exist within the genus Spicara, represented by Spicara smaris L. 1758, Spicara maena L.1758, and Spicara flexuosa (Rafinesque 1810) in the Eastern Atlantic, the Mediterranean, and the Black Sea. Certain species-specific characteristics within the Spicara genus, such as protogynous hermaphroditism (Salekhova, 1979; Karakulak et al., 2006; Sayg1lı et al., 2016) and secondary sex characteristics (e.g. size, body color and marking) (Pollard and Pichot, 1971; Arculeo et al., 1996), contribute to their confused taxonomy. Consequently, some studies (Quero et al., 2003; Eschmeyer, 2010; Froese and Pauly, 2020) suggest that $S$. 
maena and S. flexuosa should be considered as synonyms whereas others (Tortonose, 1986; Fischer et al., 1987; Costa, 1991; Louisy, 2002; Golani et al., 2006; Vasileva, 2007; Bilecenoğlu et al., 2014) support the distinction of the two species. More recent studies based on both genetic (Chiba et al., 2009; Imsiridou et al., 2011; Georgiadis et al., 2014; Bektaş et al., 2018) and morphological data (Minos et al., 2013) also support the latter conclusion. The discrepancy is reflected in various fish-related taxonomic databases as well. The Catalog of Fishes (Fricke et al., 2020), and ITIS (http://www.itis.gov) accept S. flexuosa as a valid species, while FishBase (Froese and Pauly, 2020), WoRMS, EOL and the Marine Species Identification Portal consider $S$. flexuosa as an unaccepted/unresolved and synonym of S. maena.

Regarding the biogeographical distribution of the three Spicara species, Spicara maena is of Atlanto-Mediterranean origin and inhabits temperate to warm waters, and is largely distributed in the Mediterranean, including the Adriatic Sea. It is also found from Portugal to Morocco in the Atlantic, and with a limited distribution in the Black Sea (Froese and Pauly, 2017). Spicara flexuosa is observed in the eastern Atlantic, Mediterranean, and the Black Sea (Salekhova, 1979; Tortonose, 1986; Golani et al., 2006). Finally, Spicara smaris is recorded in the Mediterranean, the Eastern Atlantic coasts, and with a restricted distribution in the Black Sea (Tortonose, 1986).

Taxonomic descriptions based on the main morphological characters of the three Spicara species are given below.

Family: Centracanthidae Gill, 1893

Genus: Spicara Rafinesque, 1810

Spicara flexuosa (Rafinesque, 1810)

Common name: Picarel. 
Diagnosis: Protrusible mouth, not more than 73 lateral line scales; head length equals or greater than body depth. Color: Clear yellowish or grey-brownish. There is a brownish spot at the base of the pectoral fin. Color varies with age, sex and season. Habitat: On sand or muddy bottoms, down to about $130 \mathrm{~m}$. Demersal schooling fish, eggs and larvae are plaktonic. Size max: 20 cm. (Tortonese, 1986; Golani et al., 2006). Spicara maena (Linneaus, 1758)

Common name: Blotched picarel.

Diagnosis: Protractile premaxilla; head length shorter than body depth, Color: Bluish grey above, sides silvery and there is also brownish dark spot at the base of the pectoral fin which is larger than S. flexuosa. Color varies with age, sex and season. Habitat: Posidonia beds, rocks and mud down to about $100 \mathrm{~m}$. Demersal spawner species. Size max: 25 cm. (Tortonese, 1986; Golani et al., 2006). Spicara smaris (Linneaus, 1758) Common name: Picarel, Zerro.

Diagnosis: Protractile premaxilla. Head length equals and longer than body depth, 75 or more lateral line scales; black spot on the body side above pectoral fin. Color: Grey above, silvery below. Color varies with age, sex and season. Habitat: Posidonia beds and muddy bottoms at about 15-100 m. Size max: $15 \mathrm{~cm}$. (Tortonese, 1986; Golani et al., 2006).

The main aim of this study was to use molecular tools based on two mitochondrial genes, cytochrome c oxidase I (COI) and cytochrome $b$ (cyt-b), and one nuclear gene, the Interphotoreceptor retinoid-binding protein (IRBP), in order to elucidate the taxonomic and phylogenetic status of Spicara flexuosa, S. maena, and S. smaris along the coasts of Turkey and the Eastern Mediterranean. Furthermore, the possible effects of the Turkish Straits System (TSS) on the evolutionary history and 
phylogeography of Spicara spp. were investigated. The TSS forms a transition zone between the Mediterranean and the Black Sea and serves as a biogeographic boundary/corridor that controls fauna and flora characteristics of the region (Öztürk and Öztürk, 1996; Magoulas et al., 1996; 2006). Finally, the results of this study were also used to determine the relative presence of $S$. maena or $S$. flexuosa along the Turkish coastal waters, as their identification based on morphology is contentious.

\section{MATERIAL AND METHODS}

\subsection{Sample collection}

We sampled 279 specimens of Spicara flexuosa and Spicara maena representing a broad geographic coverage of their distribution along the Turkish coast line and Greece (Figure 1, Supporting Information, Table S1). Individuals were collected from ten stations by fishermen using trawlers, hand line fishing and purse seine nets between 2013-2015; two from the Black Sea (Sinop, Rize, Turkey), three from the TSS (Istanbul, Armutlu, Canakkale, Turkey), two from the Central/South Aegean Sea (Izmir, Mugla, Turkey), one from the North Aegean Sea, (Kavala, Greece), and two from the Levantine Sea (Mersin, Antalya, Turkey). As there are no explicit field guides for the identification or discrimination of S. maena and S. flexuosa, information on differences based on the diagnostic morphological characters of the two species (Tortonose, 1986; Lythgoe and Lythgoe, 1992; Golani et al., 2006), along with the experience of the field collector were used to sample and identify 30 specimens of $S$. maena from Greece. These morphological differences included S. maena having: i) rather deep body than $S$. flexuosa, ii) head length being less than its body depth (vice versa for S. flexuosa), iii) head elevated posteriorly and profile concave above the head. A black mark which is larger than the one found in S. flexuosa, occurs on the side of 
the pectoral fin (Figures: 2a-d). In addition, the information that $S$. maena is encountered more often over Posidonia oceanica beds in the Aegean Sea, was used when sampling for the species with purse seine nets. The Turkish samples were initially collected as $S$. flexuosa/maena, without initial taxonomic assignment at the species level. All specimens (from Turkey and Greece) were genetically analyzed, and their species identities were determined (see subsequent analyses). GenBank entries were also included in the dataset (Figure 1, Supporting Information, Tables S1, 2, and 3). The collected tissue was preserved in $80 \%$ ethanol at room temperature and at $-20{ }^{\circ} \mathrm{C}$ in the laboratory, until further processing.

\subsection{DNA extraction and amplification}

Total genomic DNA was isolated from the muscle or caudal fin tissue with a PureLink ${ }^{\circledR}$ Genomic DNA Kit (Invitrogen, Carlsbad, USA), following the manufacturer's protocols and stored at $-20^{\circ} \mathrm{C}$. Two mitochondrial (COI, cyt-b) and one nuclear (IRBP) genes were amplified (for primers and PCR conditions used see Supporting Information, Table S4, Supporting Information, Appendix SI). All amplified products were purified and sequenced commercially (Macrogen Europe, Amsterdam, The Netherlands). The nuclear DNA products were sequenced bidirectionally to verify the presence/absence of heterozygous sites. New Spicara flexuosa and S. maena sequences have been deposited to GenBank under the following accession numbers: XX111111XX111111 for COI, YY222222- YY222222 for cyt-b, and ZZ333333-ZZ333333 for IRBP genes, respectively.

\subsection{Statistical analyses}

\subsubsection{Summary statistics}

All chromotograms were edited and aligned manually with Sequencher v.5.4.1 (GeneCodes Corp.). Potential amplification/sequencing errors were controlled by 
173 aligning all sequences to detect polymorphic sites and subsequently confirming the 174 clarity of the peaks at these sites. After trimming all ambiguous bases on both sides,

175 454, 355 and 385 bp fragments were used for further analyses of COI, cyt-b, and IRBP genes, respectively. Stop codons were investigated for mitochondrial (mtDNA) genes to determine presence/absence of mitochondrial pseudogenes by using DAMBEv.6.4.1 (Xia, 2017). In the nuclear DNA data analysis, phased haplotypes were estimated for IRBP gene using Bayesian methods in PHASE (Stephens and Donnelly, 2003). Recombination was examined using a PHI Test (Bruen et al., 2006) in SPLITSTREE 4 (Huson and Bryant, 2006). No significant signals of recombination were detected, and the full non-recombining sequences were used in the subsequent analyses.

For species assignments of each individual and gene, two approaches were applied: i) sequence similarity-based identification, and ii) phylogenetic network based identification. First, a similarity test was used between our sequences and the reference sequences in the genetic databases in BOLD and GenBank using similarity scores in BLASTn (Altschul et al., 1990) option in NCBI web-based site (https://blast.ncbi.nlm.nih.gov/Blast.cgi?PROGRAM=blastn\&PAGE_TYPE=BlastSe $\operatorname{arch} \& B L A S T \_S P E C=\& L I N K \_L O C=$ blasttab\&LAST_PAGE=tblastn). Second, a phylogenetic network construction was used to assign unidentified sequences to species based on clustering to estimate the relationship between the reference sequences and the query sequence.

To describe genetic diversity of all samples, number of haplotypes, haplotype (h) (Nei and Tajima, 1981) and nucleotide $(\pi)$ (Nei, 1987) diversities, number of polymorphic, singleton and parsimony informative sites, total number of mutations, and the average number of net nucleotide substitutions (percentage of pairwise sequence 
197

198

199

200

201

202

203

204

205

206

207

208

209

210

211

212

213

214

215

divergence) between species were calculated in DnaSP v.5.10.1 (Librado and Rozas, 2009).

\subsubsection{Haplotype networks and phylogenetic analyses}

Genealogical relationships among haplotypes of Spicara specimens were constructed per gene using the median joining method (Bandelt et al., 1999) in PopART v.1.7 (Leigh and Bryant, 2015).

Phylogenetic relationships between haplotypes were determined by neighbourjoining, maximum likelihood, and maximum parsimony methods using the software MEGA v.7.0 (Kumar et al., 2016). Nucleotide substitution models (COI: GTR; cyt-b: GTR+I; IRBP: GTR+G+I) to be used were determined using MODELTEST v.3.7 (Posada and Crandall, 1998), with the AIC (Akaike, 1974) and the Akaike's information criterion (AIC), (Hurvich and Tsai, 1989) and Bayesian Information Criterion (BIC) (Schwarz, 1978) statistics. The General Time Reversable model (GTR) that best fitted the data, was used for building the maximum likelihood trees, for the different species and gene combinations, as it is a biologically realistic model for protein coding sequences (Shapiro et al., 2006). The robustness of the trees was tested with 1,000 replicates. Neighbour-joining trees (maximum composite likelihood distances) (Tamura et al., 2004) were constructed in MEGA with 1,000 bootstrap replicates. Phylogenetic relationships were also determined with Bayesian analysis using BEAST v.2.4.8. (Bouckaert et al., 2014) under the same models above. Two independent runs of Markov Chain Monte Carlo (MCMC) for $1 \times 10^{8}$ generations with sampling every 1,000 generations were performed, whereas convergence was confirmed in Tracer v.1.6 (Rambaut et al., 2014). Spondyliosoma cantharus sequences (GenBank Accession numbers JQ624002, EU036508 and EU638155 for COI, cyt-b and IRBP genes, respectively) were included in all phylogenetic analyses as an 
outgroup. Due to the lack of publicly available Spicara smaris IRBP sequences, the phylogenetic relationships between haplotypes were determined: i) for Spicara flexuosa, S. maena and S. smaris using the concatenated COI and cyt-b dataset, ii) for all three Spicara species using the COI and cyt-b genes individually, and iii) only for S. flexuosa and S. maena for the IRBP gene.

\subsubsection{Divergence times estimates}

The evolutionary divergence time of the Spicara maena, S. flexuosa and S. smaris were estimated in BEAST using the concatenated mtDNA dataset. Sequence data from Spondyliosoma cantharus (GenBank Accession numbers were provided in 2.3.2) and Centracanthus cirrus (GenBank Accession numbers, KY176422 and MF149916) for COI and cyt-b genes, respectively, were used as outgroups. No calibration was used due to the lack of knowledge of published fossil date results. The Yule speciation process, strict clock and a molecular clock rate of $0.6 \%$ per million years for the COI gene for marine teleosts (Bermingham et al., 1997), and 2\% per million years for the cyt-b gene were used based on other Sparids (Bargelloni et al., 2003). The analysis was executed for $2.5 \times 10^{8}$ generations, sampling every 5,000 generations, and discarding the initial $10 \%$ as burn-in. Convergence was confirmed in TRACER v.1.6, and the effective sample sizes (ESS) for all model parameters were assessed, by confirming that the ESS values were higher than 200 that indicate adequate sampling intensity for all parameters.

\subsection{Genetic structure of Spicara flexuosa}

\subsubsection{AMOVA, Фst and Fst}

A hierarchical AMOVA (Analysis of Molecular Variance) was performed in Arlequin v.3.5.2.2 (Excoffier and Lischer, 2010) to test for significance between groups of 
sample collections based on the concatenated mtDNA and nuclear (nuDNA) markers. Individuals were grouped according to geographical location: i) TSS (Istanbul, Canakkale, Armutlu), ii) the Aegean Sea (Izmir, Mugla), iii) the Black Sea (Rize, Sinop), and iv) the Levantine (Antalya, Mersin). Estimations of the pairwise $\Phi_{\mathrm{ST}}$ and $F_{\text {ST }}$ for the concatenated mtDNA and nuDNA data sets, respectively, between sampling locations were conducted in Arlequin (with 10,000 permutations). Bonferroni corrections (Rice, 1989) were also used to adjust for the significance of the $P$ values for multiple tests.

\subsubsection{Demographic history analyses}

Mismatch distribution of the number of pairwise differences (Slatkin and Hudson, 1991; Rogers and Harpending, 1992) and the Tajima's $D$ (Tajima, 1989) and Fu's Fs (Fu, 1997) neutrality tests per species were estimated with DnaSP. Past population demography of S. flexuosa and S. maena was also reconstructed using Extended Bayesian Skyline Plots (EBSP) (Heled and Drummond, 2008; Ho and Shapiro, 2011), as implemented in BEAST using the multi-locus mtDNA dataset (COI, cyt-b). The BEAST input file was produced in BEAUTi v.2.4.8 (Bouckaert et al., 2014). The best model of nucleotide substitution was selected for each locus and time was scaled based on the molecular clock rates (COI and cyt-b rates were provided in 2.3.3). A strict molecular clock was set as prior and the Bayesian MCMC was run for $1.5 \times 10^{8}$ generations for both S. flexuosa and for S. maena, discarding the initial $10 \%$ of samples as burn-in. Convergence of runs was evaluated on TRACER. Visualization of the EBSP plots was made with the RStudio v.1.1.463 using R v.3.5.1 (R Development Core Team, 2018). 
273

274

275

276

\section{RESULTS}

\subsection{Summary statistics}

The COI gene was successfully amplified from 198 out of 279 Spicara individuals (175 from Turkey, 23 from Greece). The sequences of the remaining 81 individuals were either of low quality, or failed to amplify. Moreover, 57 Spicara specimens (one $S$. flexuosa; 24 S. maena, and 32 sequences of $S$. smaris) were retrieved from GenBank and the Barcode of Life Database (BOLD) (Supporting Information, Table S2) and used for further analyses. All COI sequences were perfectly matched to the reference libraries [(including Cannas et al., retrieved from GenBank, 2010, GenBank accession numbers, HM038500-HM038506)] ranging from $99.78 \%$ to $100 \%$, based on the BLASTn tool. A 454 bp fragment was used for all analyses, and a total of 18 haplotypes were found within 255 sequences.

Overall, 175 samples were identified as Spicara flexuosa and 23 as Spicara maena from the COI haplotype network (Figure 3a, for more details species identification see previous sections 2.1. and 2.3.1., and the following section 3.1.1.). Additionally, S. flexuosa had the lowest mean haplotype and nucleotide diversities ( $\mathrm{h}=0.0340, \pi=0.0001$ ). Conversely, the mean haplotype and nucleotide diversities of $S$. maena were higher than those reported for the $S$. flexuosa $(\mathrm{h}=0.6050, \pi=0.0015$, Supporting Information, Table S5). Among the S. flexuosa sampling locations, the Black Sea exhibited the highest haplotype $(\mathrm{h}=0.0650)$ and nucleotide diversities values $(\pi=0.0001)$ (Supporting Information, Table S5). Moreover, a total of $72(15.8 \%)$ nucleotide sites were variable, of which 61 positions (13.4\%) were parsimony informative (Supporting Information, Table S6; 27 for the S. maena and S. flexuosa group;18 for the S. flexuosa and S. smaris group; 16 for the S. maena and S. smaris group). The number of mutations between the three Spicara species ranged from 43 
298 (between $S$. flexuosa and S. maena) to 56 (between S. maena and S. smaris) and 299 pairwise sequence divergences ranged from $8.11 \%$ (between S. flexuosa and S. maena) 300 to $9.31 \%$ (between S. maena and S. smaris) (Supporting Information, Table S7).

301 The cyt-b gene was amplified from 157 individuals of Spicara spp. (139 from 302 Turkey, 18 from Greece). The remaining 122 individuals had either low quality 303 sequences or were not amplified, and thus were eliminated. After trimming of both ends 304 the ambiguous sequences, a 355 bp fragment was used for subsequent analyses. 305 Moreover, five S. maena, two S. flexuosa and four S. smaris sequences were added from 306 GenBank (Supporting Information, Table S3). All cyt-b sequences were matched to the 307 reference libraries [(including FishTrace, 2007, GenBank accession numbers 308 (EU036502-EU036507)], with similarities ranging from $99.72 \%$ to 100\%, based on the 309 BLASTn tool. A total of 10 haplotypes were found among 168 individuals. Among all samples, 139 fish were identified as S. flexuosa and 18 as S. maena 311 based on the cyt-b haplotype network (Figure 3b, for species identification used to see 312 aforementioned information). Spicara flexuosa exhibited the highest haplotype and 313 nucleotide diversities $(h=0.0710, \pi=0.0002)$. Specifically, Mersin $(h=0.3890$; $314 \pi=0.0011)$ and Izmir $(\mathrm{h}=0.2860 ; \pi=0.0008)$ had the highest haplotype and nucleotide 315 diversities. Region-wise, the Levantine showed the highest haplotype and nucleotide 316 diversities $(\mathrm{h}=0.1910 ; \pi=0.0005)$. (Supporting Information, Table S8). On the other 317 hand, Spicara maena showed the lowest haplotype and nucleotide diversities $(\mathrm{h}=0$, $\pi=0)$ (Supporting Information, Table S8). A total of $51(14.3 \%)$ nucleotide sites were 319 variable, of which $48(13.5 \%)$ positions were parsimony informative. A total of 17 320 positions were parsimony informative for S. flexuosa and S. maena, 14 for S. smaris 321 and S. flexuosa, and 17 for S. maena and S. smaris (Supporting Information, Table S9). 322 The total number of mutations ranged from 35 (between S. flexuosa and S. maena) to 
32337 (between $S$. flexuosa and $S$. smaris), and the pairwise sequence divergences ranged 324 from $9.01 \%$ (between S. flexuosa and S. maena) to $9.35 \%$ (between S. maena and $S$. 325 smaris) (Supporting Information, Table S7). Total number of mutations and pairwise 326 sequence divergence indicated similar levels of differentiation among the three Spicara 327 species. In addition, stop codons were not observed for the COI and cyt-b genes.

Finally, a $380 \mathrm{bp}$ fragment of the IRBP gene from 195 individuals of Spicara 329 spp. (174 from Turkey, 21 from Greece) was used for further analyses. The target gene 330 from the remaining 84 individuals either failed to amplify or resulted in low quality 331 sequences, thus eliminated from further analyses. After the addition of one $S$. maena 332 sample from France (Lautredou et al., 2013), (JX627893), a total of 38 haplotypes were 333 detected (Figure 3c). Spicara flexuosa $(\mathrm{n}=174)$ had higher mean haplotype and 334 nucleotide diversities $(\mathrm{h}=0.5030 ; \pi=0.0016)$ around the Turkish coastal waters than $S$. 335 maena $(\mathrm{n}=21)$ from Greece (North Aegean Sea) $(\mathrm{h}=0.1380 ; \pi=0.0003)$. Amongst the 336 Turkish samples, the Black Sea sampling localities had the highest haplotype and 337 nucleotide diversities $(\mathrm{h}=0.6550 ; \pi=0.0023)$, with Sinop showing the highest values $338(\mathrm{~h}=0.7150 ; \pi=0.0026)$ (Supporting Information, Table S10). Singleton variable and 339 parsimony informative sites of S. flexuosa were also higher than those of S. maena. A 340 total of 17 nucleotide sites were variable, of which eight positions (2.1\%) were 341 parsimony informative. Unlike mtDNA, only one position (243) was parsimony 342 informative for identifying S. maena and S. flexuosa (Supporting Information, Table 343 S11). The total number of mutations and pairwise sequence divergence between $S$. 344 flexuosa and S. maena were 26 and 0.0036, respectively (Supporting Information, Table 345 S7).

\subsubsection{Haplotype networks and phylogenetic analyses}


347

348

349

350

351 Information Table S2), whereas samples from Greece (Hap 10 and Hap 11), clustered

352 with S. maena samples from Sardinia (Cannas et al., retrieved from GenBank, 2010)

353 and Malta (KJ709919). In addition, 32 S. smaris samples retrieved from GenBank,

354 (GenBank numbers are found in Supporting Information Table S2) (Hap 1, Hap 2, Hap

355 3, Hap 4, Hap 5, Hap 6, Hap 7 and Hap 8) were found in the S. smaris haplogroup.

356 BLASTn results and our haplotype network descriptions showed that some of the

357 sequences deposited in GenBank and BOLD originated from Spicara genus, were

358 probably misidentified. The results indicated that one sample from Italy, 13 from Israel,

359 and six from Portugal (reported as S. maena in GenBank) (Hap 9, Hap 17), (their

360 GenBank and BOLD numbers were displayed on the Supporting Information Table S2)

361 should have been identified as $S$. flexuosa.

Similarly, three Spicara haplogroups were identified on the cyt-b gene haplotype network, according to the reference sequences (EU036502-EU036507) from the N. Aegean Sea collected for the FishTrace project (FishTrace, 2007; Zanzi and Martinsohn, 2017). Samples collected from the Turkish coastal waters (Hap 1) were clustered with S. flexuosa from Greece (GenBank, EU036502, EU036503) whereas samples collected as S. maena from Greece (Hap 6) were clustered with reference sequences of S. maena from Greece (GenBank, EU036504, EU036505) (Figure 3b). Moreover, two S. flexuosa samples from Italy (previously identified as S. maena on GenBank, AF240737; KT883671), (Hap 1) and 139 samples from Turkey were found in the S. flexuosa haplogroup. One sample from Spain, previously classified as S. maena 
372 (GenBank, EF439598) (Hap 8) was placed in the S. maena haplogroup. Finally, four $S$.

373 smaris samples from Greece (EU036506; EU036507), Italy (KT883672) and Spain 374 (EF439600) (Hap 3, Hap 4, and Hap 5) retrieved from GenBank, were in the S. smaris 375 haplogroup. BLASTn analyses corroborated our haplotype networks results.

376 Additionally, 35 haplotypes were determined as $S$. flexuosa and three as $S$. 377 maena in the IRBP haplotype network. All Greek samples (Hap 36-38) were grouped 378 with previously identified S. maena specimens from GenBank (France; Lautredou et 379 al., 2013). In contrast to the mtDNA haplotype networks, which exhibited high number 380 of mutations between S. maena and S. flexuosa (35 for COI and 30 for cyt-b), single 381 base changes were seen between the same species (Figure 3c) on the IRBP haplotype 382 network.

The concatenated COI (454 bp) and cyt-b (355 bp) data consisted of an 384 alignment of 809 bases and a total of 10 haplotypes were obtained from 119 Spicara 385 specimens (104 from Turkey and 15 from Greece), and 10 sampling locations. The 386 phylogenetic relationships revealed that S. flexuosa, S. maena, and S. smaris 387 haplogroups were clearly differentiated on the concatenated mtDNA (COI and cyt-b 388 genes) topologies (Figure 4, Supporting Information, Figures S1a-c), whilst they 389 exhibited moderate to high bootstrap $(\geq 70)$ and posterior probabilities $(\geq 0.70)$ values. 390 Additionally, S. flexuosa and S. smaris were closely related when compared to $S$. 391 maena. The same patterns were also observed for trees constructed using individual 392 COI gene (Supporting Information, Figures S2a, 3a, 4a, and 5a). On the other hand, $S$. 393 flexuosa and S. maena clades were reciprocally monophyletic with S. smaris being basal 394 in all individual cyt-b trees constructed using various phylogenetic approaches 395 (Supporting Information, Figures S2b, 3b, 4b, and 5b). Spicara flexuosa and S. maena 
396

397

398

399

400

401

402

403

404

405

406

407

408

409

410

411

412

413

414

415

416

417

418

419

420

were also generally reciprocally monophyletic in the IRBP trees (Supporting Information, Figures S6a-d).

\subsubsection{Divergence Times Estimates}

The BEAST chronogram indicated a split between Centracanthus cirrus and Spondyliosoma cantharus around 9.85 Mya (CI: 8.99-10.76). The estimated divergence time between Spondyliosoma cantharus and the three Spicara species was estimated at 6.05 Mya (CI: 5.30-6.79) (Figure 5). Within the three Spicara species, S. maena was separated from S. flexuosa and S. smaris approximately 4.30 Mya (CI: 3.50-5.08), and the split between $S$. smaris and S. flexuosa was estimated approximately 3.58 Mya (CI: 2.82-4.35).

\subsection{Genetic structure of Spicara flexuosa}

\subsubsection{AMOVA, $\Phi_{\mathrm{ST}}$ and $\boldsymbol{F}_{\mathrm{ST}}$}

Pairwise $\Phi_{\mathrm{ST}}$ values for the concatenated mtDNA dataset of Spicara flexuosa ranged from -0.19 to 0.01. Lack of genetic structure was observed among the Turkish sampling areas (Table 1). AMOVA results also indicated that variation was the highest within sampling locations $\left(102.14 \%, \Phi_{\mathrm{ST}}=-0.0213\right)$, and the lowest values were observed among locations within groups $\left(-4.74 \%, \Phi_{\mathrm{SC}}={ }_{-} 0.0486\right)$ and among the four different groups (the TSS, the Black Sea, the Aegean Sea, and the Levantine, $2.60 \%, \Phi_{\mathrm{CT}}$ $=0.0260)($ Table 2).

Pairwise $F_{\mathrm{ST}}$ values ranged from 0.00 (Rize-Canakkale; Sinop-Canakkale; Sinop-Izmir and Sinop-Rize) to 0.12 (Istanbul-Armutlu; Armutlu-Mugla). Significant $P$ values were observed between Armutlu and four other locations: Istanbul $\left(F_{\mathrm{ST}}=0.12\right)$, Mugla $\left(F_{\mathrm{ST}}=0.12\right), \operatorname{Mersin}\left(F_{\mathrm{ST}}=0.11\right)$ and Antalya $\left(F_{\mathrm{ST}}=0.07\right)$. Significant values 
were also observed between Rize and Mugla $\left(F_{\mathrm{ST}}=0.06\right)$ and Antalya and Istanbul $\left(F_{\mathrm{ST}}=0.05\right)$. (Table 1). AMOVA results showed that variation values were low and nonsignificant among the four different groups in Turkish coasts $\left(1.31 \%, F_{C T}=0.0131\right)$, whereas they were significant among and within sampling locations (2.36\%, $\left.F_{S C}=0.0239 ; 96.33 \%, F_{S T}=0.0367\right)$, respectively (Table 2).

\subsubsection{Demographic analyses of $S$. flexuosa and $S$. maena}

Neutrality tests showed that $S$. flexuosa populations had unimodal mismatch distributions for each gene (Supporting Information, Figures S7a, 7c, 7e for COI, cytb, and IRBP genes, respectively). Therefore, S. flexuosa experienced recent demographic expansion, which was corroborated by the negative and significant $F_{\mathrm{S}}$ and $D$ values (Table 3). Unimodal mismatch distributions were also observed in S. maena in all markers, suggesting recent demographic expansion (Supporting Information, Figures S7b, 7d, and 7f for COI, cyt-b, and IRBP genes, respectively). Similarly, neutrality test values $\left(F_{\mathrm{S}}\right.$ and $\left.D\right)$ were all negative, supporting the population expansion model (Table 3).

The EBSP plot of the concatenated dataset showed that the S. flexuosa population sizes remained relatively constant until about 5 Kya, followed by a sharp population growth (Figure 6a). Conversely, the $S$. maena revealed constant population sizes until about $15 \mathrm{Kya}$, followed by a subtler population growth (Figure 6b).

\section{DISCUSSION}

\subsection{Genetic differentiation of Spicara maena, Spicara flexuosa and Spicara smaris}

In this study, the distinction of the three taxa under the genus Spicara was undertaken through sequence analysis of two different mtDNA genes. The phylogenetic analyses 
using data from these two genes, different tree reconstruction algorithms, and haplotype networks, show three units with different evolutionary histories, corresponding to Spicara maena, Spicara flexuosa and Spicara smaris. For example, the phylogenetic trees based on COI gene, and the concatenated COI and cyt-b data set indicated that $S$. smaris and S. flexuosa were the most closely related to each other. On the other hand, trees based on the cyt-b gene showed that $S$. flexuosa and $S$. maena were the two most closely related species among the three. Such contradictory results have been described in the literature as well. Chiba et al. (2009) found S. flexuosa and S. smaris lineages to be reciprocally monophyletic on their cyt-b phylogenetic trees. However, Bektaş et al. (2018) showed that $S$. flexuosa and $S$. maena were the two most closely related species on their cyt-b trees.

Based on the genetic analyses (COI gene), 175 samples collected from Turkey were $S$. flexuosa. In contrast, all 23 samples collected from Greece were found to be $S$. maena, in accordance with their morphological identification during collection. In several former studies, $S$. flexuosa was reported to be present in the Turkish coastal waters (Tortonose, 1986; Salekhova, 1979; Fischer et al., 1987; Nelson, 1994; Ragonese et al., 2004; Golani et al., 2006; Turan et al., 2007; Turan, 2011; Bektaş et al., 2018). Interestingly, other studies along the Turkish coast, consider S. flexuosa and S. maena to be conspecific (Karakulak et al., 2006; Soykan et al., 2010; Keskin et al., 2011; Saygilı et al., 2016; Froese and Pauly, 2017). The result of this study indicates that the distinction of the three taxa under Spicara species is possible, as shown in previous studies (Chiba et al., 2009; Imsiridou et al., 2011; Georgiadis et al., 2014; Bektaş et al., 2018).

According to the genetic analyses (sequence similarity-based identification and phylogenetic network-based identification) carried out in this study, it appears that 
some sequences previously submitted to GenBank and BOLD have been incorrectly classified. Considering the cyt-b gene, specimens from Italy (Orrell et al., 2002; Sanciangco et al., 2016), which were previously identified as $S$. maena, actually belong to S. flexuosa. Focusing on the COI gene, a total of six sequences from Portugal (Atlantic) (Costa et al., 2012; Landi et al., 2014), one sequence from Italy, and 13 sequences from Israel (that were previously identified as S. maena in GenBank), should be classified as S. flexuosa. Landi et al. (2014) found two distinct lineages, previously identified as Spicara maena, based on barcoding (COI) sequences. Since S. flexuosa is considered as a synonym of Spicara maena in FishBase, Landi et al. (2014) indicated that one of the lineages of the Spicara maena could probably be S. flexuosa. Consequently, the main problem in studies on the Spicara genus in the Mediterranean region stems from the morphological similarity between $S$. flexuosa and S. maena. Systematic confusion due to variation in coloration, chromatic and morphological modifications during the reproductive period, and similarity between males of $S$. flexuosa and females of S. maena due to protogynous hermaphroditism (Pollard and Pichot, 1971; Arculeo et al., 1996; Vidalis and Tsimenidis, 1996; Imsiridou et al., 2011) could be some of the other possible reasons for morphological misidentification. To overcome this problem, Minos et al. (2013) evaluated similarity/dissimilarity of $S$. maena and S. flexuosa using multivariate analysis of morphometric characters. Their discriminant analysis showed that $83.2 \%$ of the examined individuals could be classified correctly by this method. Minos et al. (2013) further argued that $13 \%$ of nondiscrimination could be related to biological aspects, such as sexual dimorphism and protogynous hermaphroditism.

Estimated divergence times among the three species indicated that they began to diversify during the early or middle Pliocene (4.30-3.58 Mya), based on the analyses 
carried out using concatenated mtDNA sequences, which dates the divergence after the Messinian Salinity Crisis that took place around 6 Mya (Por, 1989). In this perspective, we propose the following scenario regarding the diversification of $S$. maena and $S$. flexuosa throughout the Atlantic, the Mediterranean and the Black Sea:

According to this scenario, S. flexuosa is considered of Atlantic-Mediterranean origin, and the species might have expanded from Atlantic to the Mediterranean and Black Sea regions. An Atlantic-Mediterranean origin was suggested for several marine taxa, such as Pagrus pagrus and Dentex dentex (Bargelloni et al., 2003), Sprattus sprattus (Debes et al., 2008), Sygnatus typhle (Wilson and Veraguth, 2010), Engraulis encrasicolus (Magoulas et al., 2006), and Mugil cephalus (Durand et al., 2013). This scenario assumes that during the early or middle Pliocene (5.00-3.50 Mya) two important events took place: The isolation of the Mediterranean Sea from the Atlantic Ocean and the cessation of the connection between the Mediterranean and the Black Sea (Moraitou-Apostolopoulou and Kiortsis, 1985). It seems probable that the differentiation of the Spicara spp. species took place in the post Messinian period (in the early or middle Pliocene) in this closed Mediterranean region, with differentiation of the ancestral S. maena and S. flexuosa having taken place in the western and eastern Mediterranean basins, respectively. An eastern Atlantic origin of S. maena is also possible. During the Pleistocene, with each glacial and interglacial cycle, S. flexuosa could have gradually expanded into the Black Sea, but might not have been able to tolerate the low salinity and temperature conditions there, as suggested by Bektaş et al. (2018), and as it has been reported for other marine fish such as the whiting (Merlangius merlangus) (Şalcığlu et al., 2020) and anchovy (Engraulis encrasicolus) (Grant, 2005). 
The expansion of $S$. flexuosa from the Mediterranean to the Black Sea might have been initiated approximately 5 Kya (the estimated time for the onset of population expansion based on the EBSP analysis) during the post glacial warming period after the end of the last glacial maximum (Ryan et al., 1997). During this period, there was outflow from Black Sea into Aegean Sea through the Bosphorus and Dardanelles (Kvasov, 1975). Hence the population expansion from the Mediterranean to the Black Sea might have occurred via the lower layer current after the opening of the Dardanelles, which occurred around 8 Kya (Ryan et al., 1997). Further and extensive sampling in the eastern Atlantic and the western Mediterranean, similar to that undertaken around Turkish coasts in this study, is necessary for a better understanding of the origins of S. flexuosa and S. maena.

\subsection{Connectivity of the Turkish Spicara flexuosa populations between Eastern}

\section{Mediterranean and Black Sea}

The absence of genetic structure between subpopulations, low values of mtDNA molecular diversity indices and star shaped haplotype networks indicate the connectivity of the S. flexuosa subpopulations from Turkey, suggesting that the TSS is a biological corridor (Turan et al., 2016), rather than a barrier to gene flow, for this species. The absence of significant genetic structure was deduced from the generally low and insignificant pairwise $\Phi_{\mathrm{ST}}$ values between populations of $S$. flexuosa along the Turkish coasts. This might have been affected by the life histories of the species (e.g. pelagic larval phase), and the TSS not being a hydrological barrier for the species, with these two effects not being mutually exclusive. The dispersal of pelagic larvae as a result of hydrological processes may enhance the gene flow between S. flexuosa from different seas, as was previously observed for other Sparid fish (Vigliola et al., 1998) and Trachurus mediterraneus, Trachurus trachurus, and Trachurus picturatus 
545 populations, based on the cyt-b gene analysis (Bektaş and Belduz, 2008), and Atlantic,

546 Mediterranean, and Aegean Trachurus populations based on 16S rRNA (Karaiskou et 547 al., 2003). Lack of genetic structure of other fish species has also been reported along 548 the Turkish coasts (Debes et al., 2008; Wilson and Veraguth, 2010; Durand et al., 2013). 549 In addition, Suziki et al. (2004) and Limborg et al. (2012) suggested that historical 550 population bottleneck resulting from strong Pleistocene glaciations was the underlying 551 reason for the low genetic structure, as well as for low level of genetic diversity in the 552 eastern Mediterranean basin, and this could also be true for the Turkish S. flexuosa 553 stock.

554 Considering overall molecular diversity of S. flexuosa, we see that the two lowest 555 haplotype $(\mathrm{h}=0.0620, \mathrm{~h}=0.0730)$ and nucleotide diversities $(\pi=0.0001, \pi=0.0002)$ were 556 found in the COI and cyt-b genes, respectively. Geographically speaking, the highest 557 haplotype and nucleotide diversities values were found in Mersin $(\mathrm{h}=0.3890, \pi=0.0010)$ 558 based on the cyt-b gene. On the other hand, certain regions showed haplotype diversities 559 that were zero, such as Black Sea region for cyt-b, and TSS for COI. Low levels of 560 genetic variability were observed in other fish species, such as Psetta maxima in 561 isolated eastern basins, including the Aegean, the Sea of Marmara, Black Sea and the 562 Azov Sea (Suziki et al., 2004). In addition, Suziki et al. (2004) found two distinct 563 lineages in the western Mediterranean and eastern Mediterranean for P. maxima, and 564 suggested that the eastern Mediterranean lineage showed lower genetic variability than 565 the western lineage, potentially due to a population bottleneck in the last glacial period 566 that took place in the Black Sea as well as in the Eastern Mediterranean. Low levels of 567 molecular diversities were also observed in the Eastern Mediterranean whiting 568 (Merlangius merlangus) as compared to Atlantic (Şalcıŏglu et al., 2020) due to potential 569 population bottleneck before the last glacial period and/or differences in population 
expansion among the Atlantic and the Eastern Mediterranean/Black Sea stocks. The results of the current study are in agreement with those of Bektaş et al. (2018), who also detected low levels of molecular diversities values for S. flexuosa along the Black Sea coast.

In addition to historical factors, more recent events such as overfishing could have contributed to small (effective) population sizes. Turan et al. (2015) reported that high fluctuations of total catch and heavy fishing pressure were probably the main reasons for low levels of genetic variation of Sarda sarda among the Turkish coastal waters. In recent years, S. flexuosa/maena have been exposed to heavy fishing pressure and their annual production have drastically decreased from a total of 2.250 tons in 2001 to 218 tons in 2019 (TUIK, 2019). Thus, its populations might have been severely impacted, likely resulting in a decrease of the population numbers.

Star-shaped haplotype networks of the mtDNA genes of $S$. flexuosa recorded in the present study indicate that the species might have also undergone a population expansion in the past. The network also shows the connectivity of S. flexuosa sampling locations as has been previously observed for other protogynous hermaphrodite fish (e.g., Pagellus bogavareo, Bargelloni et al., 2003; Stockley et al., 2005), protandrous hermaphrodite fish (e.g., Diplodus puntazzo, (Bargelloni et al., 2005), and fresh to brackish water fish (e.g., Coregonus clupeaformis, Bernatchez et al., 1989). Neutrality test results (significantly negative $F_{S}$ and Tajima $D$ values), unimodal mismatch distribution and EBSP also support the scenario of sudden population growth (5 Kya) of S. flexuosa after a potential bottleneck in the eastern Mediterranean. Wilson and Veraguth (2010) also detected unimodal mismatch distributions among Syngnathus typhle (pipefish) from the Black Sea and the Sea of Marmara. In addition, a star-shaped haplotype network and a recent and sharp expansion of a single whiting lineage were 
595 also reported from the Eastern Mediterranean, Black Sea, the TSS, and the North 596 Aegean Sea (Şalcıoglu et al., 2020). As opposed to these results, Debes et al. (2008) 597 found ragged mismatch distribution among the European sprat populations between the 598 Black Sea and the Bosphorus, not supporting a scenario of demographic expansion after 599 having a small population size. Hence, along the Turkish coasts and TSS, the 600 presence/absence of bottleneck and demographic expansion scenarios can be species601 Nuclear DNA analysis results of S. flexuosa and S. maena revealed that the 603 previous phylogenetic analyses were in accordance with the taxonomies of the two 604 species as no haplotypes were shared between them. The genetic differentiation 605 between these two species of Spicara confirms that reproductive isolation of the two 606 species was complete. Moreover, the total number of mutations and the number of parsimony informative sites between the two Spicara species were not as high in the IRBP gene as those between the mtDNA genes, suggesting that the lack of the 609 discrimination could be due to slower evolution rate of the former (Verma et al., 2004).

\section{CONCLUSION AND RECOMMENDATIONS}

612 In this study, molecular taxonomy, phylogeography of Spicara spp. around the Turkish 613 and Eastern Mediterranean coasts were investigated. The three species of Spicara were 614 clearly distinguished by two different mtDNA markers. Although not as clear-cut as in mtDNA, the nuDNA also showed the differentiation of S. maena and S. flexuosa. The result of the dating analyses suggested that the three Spicara species were differentiated

617 during the early or middle Pliocene (4.30-3.58 Mya). Considering, S. flexuosa, low 618 values of mtDNA molecular diversity indices, an absence of genetic structure between subpopulations, and star-shaped haplotype networks indicate the connectivity of the 
examined $S$. flexuosa sampling locations from Turkey, suggesting that the TSS is a corridor, rather than a barrier to gene flow, for this species. Moreover, demographic analysis supports the scenario of sudden population growth of S. flexuosa after a potential bottleneck. Based on the EBSP analysis, S. flexuosa and S. maena expansions were relatively recent (ca. 5 Kya and $15 \mathrm{Kya}$, respectively) along the Eastern Mediterranean. S. flexuosa is currently considered as a synonym of S. maena, and therefore, data on its population statistics have not been reported in the literature. This is a significant problem, as it can result in inaccurate determination and assessment of current stock levels for both S. maena and S. flexuosa. As picarel populations have experienced rapid decline in the Black Sea, Aegean and Eastern Mediterranean in the last 10 years (Pollard et al., 2014), it is recommended that separate statistics and population studies should be used for conservation and management decisions for $S$. maena and S. flexuosa.

\section{Acknowledgements}

This study was supported by a grant (No: 1903) from the Research Fund of Boğaziçi University in Istanbul, Turkey to Raşit Bilgin. We would like to thank D. Innal (Mehmet Akif Ersoy University, Burdur, Turkey), D. Guroy (Yalova University, Turkey) and anonymous fishermen from the Sea of Marmara, Black Sea and Aegean Sea for providing fish samples. The authors declare that they have no conflict of interest. All authors read and approved the final version of the manuscript. Finally, we are thankful to two anonymous reviewers for their comments on a previous version of the manuscript.

\section{Ethical Issue}

The work raises no ethical issues. All fish examined were from commercial fishing activities and none of them were killed for the specific purpose of the study. 
645

646

647

648

649

650

651

652

653

654

655

656

657

658

659

660

661

662

663

664

665

666

667

\section{REFERENCES}

Akaike, H. 1974. A new look at the statistical model identification. IEEE Transactions on Automatic Control 19(6): 716-723.

Altschul, S.F.; Gish, W.; Miller, W.; Myers, E.W.; Lipman, D.J. 1990. Basic local alignment search tool. J. Mol. Biol. 215, 403-410.

Arculeo, M., Mauro, A., Scelsa, G., Lo Brutto, S., Cammarata, M., and Parrinello, N. 1996. Protein differences among the Mediterranean species of the genus Spicara. J. Fish Biol. 49: 1317-1322.

Bandelt, H.J., Forster, P., and Rohl, A. 1999. Median-Joining Networks for Inferring Intraspecific Phylogenies. Mol. Biol. Evol. 16: 37-48. https://doi.org/10.1093/oxfordjournals.molbev.a026036.

Bargelloni, L., Alarcon, J.A., Alvarez, M.C., Penzo, E., Margoulas, A., Reis, C., and Patarnello, T. 2003. Discord in the family Sparidae (Teleostei): divergent phylogeographical patterns across the Atlantic-Mediterranean divide. J. Evol. Biol. 16: 1149-1158. https://doi.org/ 10.1046/j.1420-9101.2003.00620.x.

Bargelloni, L., Alarcon, J.A., Alvarez, M.C., Penzo, E., Margoulas, J. Palma, A., and Patarnello, T. 2005. The Atlantic-Mediterranean transition: Discordant genetic patterns in two seabream species, Diplodus puntazzo (Cetti) and Diplodus sargus (L). Mol. Phylogenet. Evol. $36 \quad$ (3): 523-535. https://doi.org/10.1016/j.ympev.2005.04.017.

Bauchot, M.L. and Hureau, J.C. 1986. Sparidae. In: Fishes of the North-Eastern Atlantic and the Mediterranean, Vol. II. Whitehead PJP, Bauchot ML, Hureau JC, Nielsen E, Tortonese (Eds), 883-907, UNESCO, Paris. 
668

669

670

671

672

673

674

675

676

677

678

679

680

681

682

683

684

685

686

687

688

689

690

691

Bektaş, Y., and Belduz, A.O. 2008. Molecular phylogeny of Turkish Trachurus species (Perciformes: Carangidae) inferred from mitochondrial DNA analyses. J. Fish Biol. 73: 1228-1248. https://doi.org/ 10.1111/j.1095-8649.2008.01996.x.

Bektaş, Y., Aksu, İ., Kalayci, G., Irmak, E., Engin, S. Turan, D. 2018. Genetic differentiation of three Spicara (Pisces: Centracanthidae) species, S. maena, S. flexuosa and S. smaris: and intraspecific substructure of S. flexuosa in Turkish coastal waters. Turk. J. Fish Aquat Sc. 18: 301-311. doi: 10.4194/1303-2712v18_2_09.

Bermingham, E., McCajerty, S.S., and Martin, A.P. 1997. Fish biogeography and molecular clocks: perspectives from the Panamanian Isthmus. In Molecular systematics of fishes (ed. T. D. Kocher \& C. A. Stepien), pp.113-128. San Diego: Academic Press.

Bernatchez, L., Dodson, J.J., and Bolvin, S. 1989. Population bottlenecks influence on mitochondrial DNA diversity and its effect on coregonine stock discrimination. J. Fish Biol. 35:233-244. https://doi.org/10.1111/j.1095-8649.1989.tb03066.x.

Bilecenoğlu, M., Kaya M., Cihangir, B., and Çiçek, E. 2014. An updated checklist of the marine fishes of Turkey. Turk. J. Zool. 38: 901-929.doi:10.3906/zoo-140560.

Bouckaert, R., Heled, J., Kühnert, D., Vaughan, T., Wu, C.H., Xie, D., Suchard, M.A., Rambaut, A., and Drummond A.J. 2014. BEAST 2: a software platform for Bayesian evolutionary analysis. PLoS Comp. Biol. 10(4): e1003537.https://doi.org/10.1371/ journal.pcbi.1003537.

Bruen, T.C., Philippe, H., and Bryant, D. 2006. A simple and robust statistical test for detecting the presence of recombination. Genetics, 172: 2665-2681. 
692

693

694

695

696

697

698

699

700

701

702

703

704

705

706

707

708

709

710

711

712

713

714

715

716

[dataset] Cannas, R., Manunza, A., Sabatini, A., and Cau, A. 2010. Molecular evidence of the erroneous synonimization of Spicara flexuosa and S. maena as a single species and of the polyphyly of the Centracanthidae family. GenBank. Available from:https://www.ncbi.nlm.nih.gov/nuccore/HM038500.1;https://www.ncbi.nl m.nih.gov/nuccore/HM038501;https://www.ncbi.nlm.nih.gov/nuccore/HM038 502;,https://www.ncbi.nlm.nih.gov/nuccore/HM038503;https://www.ncbi.nlm. nih.gov/nuccore/HM038505;https://www.ncbi.nlm.nih.gov/nuccore/HM03850 6.

Chiba, S.N., Iwatsuki, Y., Yoshino, T., and Hanzawa, N. 2009. Comprehensive phylogeny of the family Sparidae (Perciformes: Teleostei) inferred from mitochondrial gene analyses. Gen. Gene. Syst. 84: 153-170. https://doi.org/10.1266/ggs.84.153.

Costa, F. 1991. Atlante dei pesci dei mari italiani. Mursia Editore, Milano, 1-429. (in Italian).

Costa, F., Landi, M., Martins, R., Costa, M.H., Costa, M.E., Carneiro, M., Alves, M.J., Steinke, D., and Carvalho, G.R. 2012. A Ranking System for Reference Libraries of DNA Barcodes: Application to Marine Fish Species from Portugal. PLoS One, 7(4): 1-9. https:// doi: 10.1371/journal.pone.0035858.

Debes, P.V., Zachos, E., and Hanel, R. 2008. Mitochondrial phylogeography of the European sprat (Sprattus sprattus L., Clupeidae) reveals isolated climatically vulnerable populations in the Mediterranean Sea and range expansion in the northeast Atlantic. Mol. Ecol. 17: 3873-3888. doi: 10.1111/j.1365294X.2008.03872.x.

Durand, J.D., Blel, H., Shen, K.N., Koutrakis, E.T., and Guinand, B. 2013. Population genetic structure of Mugil cephalus in the Mediterranean and Black Seas: a 

single mitochondrial clade and many nuclear barriers. Mar. Ecol. Prog. Ser. 474: 243-261. doi: 10.3354/meps10080.

EOL. Encyclopedia of Life. Available from http://eol.org. Accessed 15 July 2020. https://eol.org/pages/46578158.

Eschmeyer, W.N. 2010. Catalog of Fishes. Available at http://research.calacademy.org/ ichthyology/catalog/fishcatmain.asp.

Excoffier, L., and Lischer, H.L. 2010. Arlequin suite ver 3.5: A new series of programs to perform population genetics analyses under Linux and Windows. Mol. Ecol. Res. 10: 564-567. https://doi.org/ 10.1111/j.1755-0998.2010.02847.x.

FishTrace. 2007. Genetic Catalogue, Biological Reference Collections and Online Database of $\quad$ European $\quad$ Marine https://fishtrace.jrc.ec.europa.eu/index.html.

Fischer, W., Bauchot, M.L., and Schneider, M. 1987. Fiches FAO d'identification des espèces pour les besoins de la pêche. (Revision 1). Mediterranee et mer Noire. Zone de pêche 37. Volume II. Vertébrés. Publication préparée par la FAO, résultat d'un accord entre la FAO et la Commission des Communautes Europeennes (Project GCP/INT/422/EEC) financée conjointement par ces deux organisations. Rome, FAO, 2,761-1530. (in French).

Fricke, R., Eschmeyer, W.N. and Van der Laan, R. (eds). 2020. ESCHMEYER'S CATALOG OF FISHES: GENERA, SPECIES, REFERENCES. (http://researcharchive.calacademy.org/research/ichthyology/catalog/fishcatma in.asp). Electronic version accessed 07.06.2020.

Froese R., and Pauly, D., (Eds.). 2017. FishBase. World Wide Web Electronic Publication. www.fishbase.org, http://www.fishbase.se/summary/. html. (accessed, November 2017). 
Froese, R., and Pauly, D., (Eds.). 2020. FishBase. World Wide Web Electronic Publication. www.fishbase.org, http://www.fishbase.se/summary/Spicaramaena. html. (accessed, May 2020).

Froese, R., and Pauly, D., (Eds.). 2020. WoRMS, Spicara maena (Linnaeus, 1758). Accessed through: World Register of Marine Species at: http://www.marinespecies.org/aphia.php?p=taxdetails\&id=126828 on 202006-07.

Froese, R., and Pauly. D., (Eds). 2020. WoRMS, Spicara flexuosa (Rafinesque, 1810). Accessed through: World Register of Marine Species at: http://www.marinespecies.org/aphia.php?p=taxdetails\&id=302566 on 202006-07.

Fu, Y.X. 1997. Statistical tests of neutrality of mutations against population growth, hitchhiking and background selection. Genetics, 147(2): 915-925.

Garcia-Vazquez, E.G., Schiaffino-Machado, G., Campo, D., and Juanes, F. 2012. Species Misidentification in Mixed Hake Fisheries May Lead to Overexploitation and Population Bottlenecks. Fish. Res. 114: 52-55. doi:10.1016/j.fishres.2011.05.012.

Georgiadis, A., Sandaltzopoulos, R., Stergiou, K.I., and Apostolidis, A.P. 2014. Meltcurve-multiplex-haplotype-specific-PCR, a valuable tool for biological studies: Application in congeneric species discrimination assay. Biochem. Syst. Ecol. 56: 271-277. https://doi.org/10.1016/j.bse.2014.07.013.

Golani, D., Öztürk, B., and Başusta, N. 2006. Centracanthidae, In: Fishes of the Eastern Mediterranean. Golani, D., Öztürk, B., Başusta, N. (Eds). Turkish Marine Research Foundation, Istanbul, pp. 168-169. 
Grant, W.S. 2005. A second look at mitochondrial DNA variability in European anchovy (Engraulis encrasicolus): assessing models of population structure and the Black Sea isolation hypothesis. Genetica, 125: 293-309.

Heled, J., and Drummond, A.J. 2008. Bayesian inference of population size history from multiple loci. BMC Evol. Biol. 8: 289. https://doi.org/10.1186/1471-21488-289.

Ho, S.Y.W., and Shapiro, B. 2011. Skyline-plot methods for estimating demographic history from nucleotide sequences. Mol. Ecol. Res. 11: 423-434. https://doi.org/10.1111/j. 1755-0998.2011.02988.x

Hurvich, C.M., and Tsai, C.L. 1989. Regression and time series model selection in small samples. Biometrika, 76: 297-307.

Huson, D.H., and Bryant, D. 2006. Application of phylogenetic networks in evolutionary studies. Mol. Biol. Evol .23: 254-267.

Imsiridou, A., Minos, G., Gakopoulou, A., Katsares, V., Karidas, T., and Katselis, G. 2011. Discrimination of two picarel species Spicara flexuosa and Spicara maena (Pisces: Centracanthidae) based on mitochondrial DNA sequences. J. Fish Biol. 78: 373-377. doi: 10.1111/j.1095-8649.2010.02858.x.

ITIS. 2020. from the Integrated Taxonomic Information System on-line database, http://www.itis.gov.

Karaiskou, N., Apostolidis, A.P., Triantafyllidis, A., Kouvatsi, A., and Triantaphyllidis, C. 2003. Genetic Identification and Phylogeny of Three Species of the Genus Trachurus based on Mitochondrial DNA Analysis. Mar. Biotechnol. 5: 493504. 10.1007/s10126-002-0099-5. 
789 Karakulak, F.S., Erk, H., and Bilgin, B. 2006. Length-weight relationships for 47

790

791

792

793

794

795

796

797

798

799

800

801

802

803

804

805

806

807

808

809

810

811

812 coastal fish species from the northern Aegean Sea, Turkey. J. App. Ichth. 22: 274-278. https://doi.org/10.1111/j.1439-0426.2006.00736.x.

Keskin, Ç., Turan, C., and Ergüden, D. 2011. Distribution of the Demersal Fishes on the Continental Shelves of the Levantine and North Aegean Seas (Eastern Mediterranean). Turk. J. Fish Aquat. Sc. 11: 413-423. doi: 10.4194/trjfas.2011.0311.

Kumar, S., Stecher, G., and Tamura, K. 2016. MEGA7: Molecular Evolutionary Genetics Analysis Version 7.0 for Bigger Datasets. Mol. Biol. Evol. 33 (7): 1870-1874. https://doi.org/10.1093/molbev/msw054.

Kvasov, D.D. 1975. Pozdnechetvertichnaya istoriya krupnykh ozer i vnutrennikh morei Vostochnoi Evropy [(Late Quaternary History of Large Lakes and Inland Seas of Eastern Europe)], Leningrad, Nauka, 1-278. (in Russian).

Landi, M., Dimech, M., Arculeo, M., Biondo, G., Martins, R., Carneiro, M., Carvalho, G.R., Lo Brutto, S., and Costa, F.O. 2014. DNA barcoding for species assignment: The case of Mediterranean marine fishes. PLoS One, 9(9): 1-9. doi: 10.1371/journal.pone.0106135.

Lautredou, A.C., Motomura, H., Gallut, C., Ozouf-Costaz, C., Cruaud, C., Lecointre, G., and Dettai, A. 2013. New nuclear markers and exploration of the relationships among Serraniformes (Acanthomorpha, Teleostei): The importance of working at multiple scales. Mol. Phylogenet. Evol. 67: 140-155. doi: 10.1016/j.ympev.2012.12.020.

Leigh, J.W., and Bryant, D. 2015. POPART: full features of the software for haplotype network construction. Methods Ecol. Evol. 6: 1110-1116. 
Li, C., Jiang, S., Schneider, .K., Jin, J., Lin, H., Wang, J., Elmer, K.R., and Zhao, J. 2020. Cryptic species in White Cloud Mountain minnow, Tanichthys albonubes: Taxonomic and conservation implications. Mol. Phylogenet. Evol. 153: 106950, https://doi.org/10.1016/j.ympev.2020.106950.

Librado, P., and Rozas, J. 2009. DnaSPv5: A Software for comprehensive analysis of DNA polymorphism data. Bioinformatics, 25: 1451-1452.

Limborg, M.T., Hanel, R., Debes, P.V., Ring, R., Andre, C., Tsigenopoulos, C.S., and Bekkevold, D. 2012. Imprints from genetic drift and mutation imply relative divergence times across marine transition zones in a pan-European small pelagic fish (Sprattus $\quad$ sprattus). $\quad$ Heredity, 109: 96-107. https://doi.org/10.1038/hdy.2012.18.

Louisy, P. 2002. Guide d'identifications des Poissons Marins. Europe de l'ouest et M'editerran'ee. Paris: ULMER, 1-430. (In French).

Lythgoe, J.N., Lythgoe, G.I. 1992. Fishes of the Sea: the North Atlantic and Mediterranean. 1st MIT Press edition, Cambridge, MIT press, 1-256.

Magoulas, A.N., Tsimenides, N., Zouros, E., 1996. Mitochondrial DNA phylogeny and the reconstruction of the population history of a species: the case of the European anchovy (Engraulis encrasicolus). Mol. Biol. Evol. 13, 178-190. https://doi.org/10. 1093/oxfordjournals.molbev.a025554.

Magoulas, A., Castilho, R., Caetano, S., Marcato, S., and Patarnello, T. 2006. Mitochondrial DNA reveals a mosaic pattern of phylogeographical structure in Atlantic and Mediterranean populations of anchovy (Engraulis encrasicolus). Mol Phylogenet. Evol.

39: 734-746. https://doi.org/10.1016/j.ympev.2006.01.016. 
837

838

839

840

841

842

843

844

845

846

847

848

849

850

851

852

853

854

855

856

857

858

859

860

861

Moraitou-Apostolopoulou, M., and Kiortsis, V. 1985. Mediterranean Marine Ecosystems, Proceeding of a NATO ARW on Mediterranean Marine Eosystem, (September 23- 27, 1983), Crete, Greece. Springer, Science, Business Media, New York, 1-407.

Minos, G., Imsiridou, A., and Katselis, G. 2013. Use of morphological differences for the identification of two picarel species Spicara flexuosa and Spicara maena (Pisces: Centracanthidae). Med. Mar. Sci. 14(3): 26-31. http://dx.doi.org/10.12681/mms.423.

National Center for Biotechnology Information (NCBI-[access 09 .11. 2017]. Available from:https://www.ncbi.nlm.nih.gov/(https://blast.ncbi.nlm.nih.gov/Blast.cgi?P ROGRAM=blastn\&PAGE_TYPE=BlastSearch\&BLAST_SPEC=\&LINK_LO $\mathrm{C}=$ blasttab\&LAST_PAGE=tblastn).

Nei, M., Tajima, F. 1981. DNA polymorphism detectable by restriction endonucleases. Genetics, 97(1): 145-163.

Nei, M. 1987. Molecular Evolutionary Genetics. Columbia University Press, New York, 1-512.

Nelson, J.S. 1994. Fishes of the World. Third Edition. John Wiley \& Sons, Inc., New York, pp.1-600.

Nelson, J.S., Grande T.C., and Wilson, M.V.H. 2016. Fishes of the World. 5th edition. John Wiley \& Sons, Hoboken, N.J. pp.707

Orrell, T.M., and Carpenter, K.E. 2004. A phylogeny of the fish family Sparidae (porgies) inferred from mitochondrial sequence data. Mol. Phylogenet. Evol. 32: 425-434. doi: 10.1016/j.ympev.2004.01.012.

Orrell, T.M., Carpenter, K.E., Musick, J.A., and Graves, C.E. 2002. A phylogenetic and biogeographic analysis of the Sparidae (Perciformes: Percoidei) based on 
cytochrome b sequences. Copeia, 3: 618-631. doi: 10.1643/00458511(2002)002[0618:PABAOT]2.0.CO;2.

Öztürk, B., Öztürk, A.A. 1996. On the Biology of the Turkish Straits System. Bulletin de l'Institut Ocanographique, Monaco no special 17. CIESM Science Series n2. 205-221.

Parenti, P. 2019. An annotated checklist of the fishes of the family Sparidae. FishTaxa, 4(2): 47-98.

Pollard, D.A., and Pinchot, P. 1971. The systematic status of the Mediterranean Centracanthidae fishes of the genus Spicara, and in particular S. chryselis (Val.) as indicated by electrophoresis studies of their eye-lens proteins. J Fish Bio. 3: $59-72$.

Pollard, D., Carpenter, K.E., and Russell, B. 2014. Spicara maena. The IUCN Red List of Threatened $\quad$ Species 2014: e.T170280A1307759. http://dx.doi.org/10.2305/IUCN.UK.2014-3.RLTS.T170280A1307759.

Por, F.D. 1989. The Legacy of Tethys. An Aquatic Biogeography of the Levantine. Dordrecht, Kluwer Academic, Springer, Dordrecht, Netherlands, 1-214.

Posada, D., and Crandall, K.A. 1998. MODELTEST: testing the model of DNA substitution. Bioinformatics, 14(9): 817-818. https://doi.org/10.1093/bioinformatics/14.9.817.

Quero, J.C., Porche, P., and Vayne, J.J. 2003. Guide des poisons de l'Atlantique europ'een (les guides du naturaliste). Lonay (Switzerland) and Paris: Delachaux et Niestl'e, 1-304. (in French).

R Development Core Team, 2018. R: A language and environment for statistical computing. R Foundation for Statistical Computing, Vienna, Austria. URL, https://www.R-project.org/. 
887

888

889

890

891

892

893

894

895

896

897

898

899

900

901

902

903

904

905

906

907

908

909

Ragonese, S., Fiorentino, F., Garofalo, G., Gristina, M., and Levi, D. 2004. Distribution, abundance and biological features of picarel (Spicara flexuosa), Mediterranean (Trachurus mediterraneus) and Atlantic (T. trachurus) horse mackerel based on experimental bottom-trawl data (MEDITS, 1994-2002) in the Strait of Sicily. p. 100-114. In: Report of the Med Sud Med Expert Consultation on Small Pelagic Fishes: Stock Identification and Oceanographic Processes Influencing their Abundance and Distribution. MedSudMed (Eds). GCP/RER/010/ ITA/MSM-TD-05. MedSudMed Technical Documents 5.

Rambaut, A., Suchard, M.A., Xie, D., and Drummond, A.J. 2014. Tracer v1.6, Available from http://beast.bio.ed.ac.uk/Tracer.

Rice, W.R. 1989. Analyzing tables of statistical tests. Evolution, 43(1), 223-225. https:// doi.org/10.1111/j.1558-5646.1989.tb04220.x.

Rocha, L.A., Craig, M.T., and Bowen, B.W. 2007. Phylogeography and the conservation of coral reef fishes. Coral Reefs, 26: 501-512.

Rocha, L.A., Rocha, C.R., Robertson, D.R., and Bowen, B.W. 2008. Comparative phylogeography of Atlantic reef fishes indicates both origin and accumulation of diversity in the Caribbean. BMC Evol. Biol, 8: 157.

Rogers, A.R., and Harpending, H. 1992. Population growth makes waves in the distribution of pairwise genetic differences. Mol. Biol. Evol. 9 (3): 552-569. https://doi.org/10.1093/oxfordjournals.molbev.a040727.

Ryan, W.B.F., Pitmann, W.C., Major, C., Shimkus, K., Moskalenko, V, Jones, G.A., Dimitrov, P., Görür, N., Sakinc, M., and Yüce, H. 1997. An abrupt drowning of the Black Sea shelf: Mar. Geol. 138: 119-126. 
910

911

912

913

914

915

916

917

918

919

920

921

922

923

924

925

926

927

928

929

930

931

932

933

934

Salekhova, L.P. 1979. Centracanthidae fishes of the genus Spicara from the Mediterranean and Black Sea. Haykova-Dumka, Kiev Academy of the Science, $1-172$.

Sanciangco, M.D., Carpenter, K.E., and Betancur, R.R. 2016. Phylogenetic placement of enigmatic percomorph families (Teleostei: Percomorphaceae) Mol. Phylogenet. Evol. 94: 565-576.

Sayg1l1, B., İşmen, A. and İhsanoğlu, M.A. 2016. Age and growth of blotched picarel (Spicara maena Linnaeus, 1758) in the Sea of Marmara and Northern Aegean Sea. Ege J. Fish. 33(2): 143-149. doi: 10.12714/egejfas.2016.33.2.08.

Schwarz, G. 1978. Estimation the dimension of a model. Ann Stat. 6: 461464.https://www.jstor.org/stable/2958889.

Shapiro, B, Rambaut A, and Drummond A.J. 2006. Choosing appropriate substitution models for the phylogenetic analysis of protein-coding sequences. Mol. Biol Evol. 23: 7-9.

Slatkin, M., and Hudson, R.R. 1991. Pairwise comparisons of mitochondrial DNA sequences in stable and exponentially growing populations. Genetics, 129(2): $555-562$.

Soykan, O., İlkyaz, A.T., Metin, G., and Kınacigil, H.T. 2010. Growth and reproduction of blotched picarel (Spicara maena) Linnaeus, 1758, in the central Aegean Sea, Turkey. Turk. J. Zool. 34: 453-459. doi:10.3906/zoo-0903-29.

Stephens, M., Donnelly, P. 2003. A comparison of Bayesian methods for haplotype reconstruction from population genotype data. The American Journal of Human Genetics, 73: 1162-1169.

Stockley, B., Menezes, G.E., Pinho, M.R., and Rogers, A.D. 2005. Genetic population structure in the black-spot sea bream (Pagellus bogaverou, (Brunnich, 1768) 

from the NE Atlantic. Mar. Biol. 146: 793-804. https://doi.org/10.1007/s00227004-1479-3.

Sugawara, T., Terai, Y., and Okada, N. 2002. Natural selection of the rhodopsin gene during the adaptive radiation of East African Great Lakes cichlid fishes. Mol. Biol. Evol. 19: 1807-1811.

Suziki, N., Nishida, M., Yoseda, K., Üstündağ, C., Şahin, T., and Amaoka, K. 2004. Phylogeographic relationships within the Mediterranean turbot inferred by mitochondrial DNA haplotype variation. J. Fish Biol. 65: 580-585. https://doi.org/10. 1111/j.1095-8649.2004.00433.x.

Şalcıoğlu, A., Gubili, C., Krey, G., Sönmez, A.Y., and Bilgin, R. 2020. Phylogeography and population dynamics of the Eastern Mediterranean whiting (Merlangius merlangus) from the Black Sea, the Turkish Straits System, and the North $\begin{array}{llll}\text { Aegean } & \text { Sea. } & \text { Fish. } & \text { Res. }\end{array}$ https://doi.org/10.1016/j.fishres.2020.105614.

Tajima, F. 1989. Statistical method for testing the neutral mutation hypothesis by DNA polymorphism. Genetics, 123 (3): 585-595.

Tamura, K., Nei, M., and Kumar, S. 2004. Prospects for inferring very large phylogenies by using the neighbour-joining method. PNAS 101: 11030-11035. https://doi.org/10.1073/pnas.0404206101.

Teletchea, F. 2009. Molecular identification methods of fish species: reassessment and possible applications. Rev. Fish. Biol. Fish. 19: 265-293.

Tillett, B. J., Field, I.C., Bradshawd, C. J. A., Johnson, G., Buckworth, R. C., Meekan, M.G., Ovendenh, J.R. 2012. Accuracy of species identification by fisheries observers in a north Australian shark fishery. Fish. Res. 127-128: 109-115. https://doi.org/10.1016/j.fishres.2012.04.007. 
Tortonose, E. 1986. Centracanthidae. In Fish of the North-eastern Atlantic and Mediterranean (Whitehead, P. J. P., Bauchot, M. L., Hureau, J. C., Nielsen, J. \& Tortonese, E., eds), Paris: UNESCO, 2, 908-911.

TUIKK. 2019. Su Ürünleri Istatistikleri Veri Tabanı.[Turkish Statiscs DataBase]. http://tuik.gov.tr/PreTablo.do?alt_id=1005.

Turan, C., Öztürk, B., Ergüden, D., Gürlek, M., Yağlığlu, D., and Uygur, N. 2007. Atlas of marine bony fishes of Turkey. In: Atlas and Systematic of Marine Bony Fishes of Turkey ((ed.) C. Turan)). Nobel Publishing House, Adana, Turkey.

Turan, C. 2011. The systematic status of the Mediterranean Spicara species (Centracanthidae) inferred from mitochondrial $16 \mathrm{~S}$ rDNA sequence and morphological data. Journal of Black Sea/Mediterranean Environment 17: 1431.

Turan, C., Gürlek, M., Ergüden, D., Yağlioglu, D., Uyan, A., Reyhaniye, A.N., Özbalcilar, B., Öztürk, B., Erdoğan, Z.A., Ivanova, P., and Soldo, A. 2015. Population genetic analysis of Atlantic bonito Sarda sarda (Bloch, 1793) using sequence analysis of mtDNA D-loop region. Fres. Environ. Bull. 24: 31483154.

Turan, C., Ivanova, P., and Soldo, A. 2016. Population Structuring and Migration Pathway of Atlantic bonito Sarda sarda. Nat. Eng. Sci. 1(3): 56-65.

Vasileva, E.D. 2007. Fish of the Black Sea. Key to Marine, Brackish-water, Euryhaline, and Anadromous Species with Color Illustrations, Collected by S. V. Bogorodsky. Moscow: VNIRO Publishing.

Vecchione, M., Mickevich, M.F., Fauchald, K., Collette, B.B., Williams, A.B., Munroe, T.A., Young, R.E. 2000. Importance of assessing taxonomic adequacy in 

determining fishing efects on marine biodiversity. ICES J. Mar. Sci. 57: 677681. https://doi.org/10.1006/jmsc.2000.0707.

Verma, S.K., Sinha, R.K., and Singh, L. 2004. Phylogenetic position of Platanista gangetica: insights from the mitochondrial cytochrome $\mathrm{b}$ and nuclear interphotoreceptor retinoid binding protein gene sequences. Mol. Phylogenet. Evol. 33: 280-288.

Vidalis, K., Tsimenidis, N., 1996. Age determination and growth of picarel (Spicara smaris) from the Cretan continental shelf (Greece). Fish. Res.: 28, 395-421.

Vigliola, L., Harmelin-Vivien, M.L., Biagi, F., Galzin, R., García Rubies, A., Harmelin, J.G., Jouvenel, J.Y., Le Dieach-Boursier, L., Macpherson, E. and Tunesi, L. 1998. Spatial and temporal patterns of settlement among Diplodus Sparid fishes in the northwestern Mediterranean. Mar. Ecol. Prog. Series 168: 45-56. http://www.jstor.org/stable/24828359.

Wilson, A.B., and Veraguth, I.E. 2010. The impact of Pleistocene glaciation across the range of a widespread European coastal species. Mol. Ecol. 19:4535-4553. https://doi.org/10.1111/j.1365-294X.2010.04811.x.

Xia, X. 2017. DAMBE6. New tools for microbial genomic, phylogenetics and molecular evolution. J. Hered. 108: 431-437. https://doi.org/10.1093/jhered/esx033.

Zanzi, A., Martinsohn, J.T. 2017. FishTrace: a genetic catalogue of European fishes. Database, 2017, 1-11. https://doi: 10.1093/database/bax075. 
1010 Table 1. Pairwise $\Phi_{\mathrm{ST}}$ values of the concatenated data of COI + cyt-b genes (below diagonal) and Fst values of IRBP genes (above diagonal) of S. flexuosa. Values in italics and bold were significant before and after Bonferroni corrections, respectively. TSS: Turkish Strait System.

\begin{tabular}{|c|c|c|c|c|c|c|c|c|c|c|c|}
\hline & & & İstanbul & Çanakkale & Armutlu & İzmir & Muğla & Rize & Sinop & Antalya & Mersin \\
\hline \multirow{9}{*}{$\begin{array}{l}\text { Spicara } \\
\text { flexuosa }\end{array}$} & \multirow[t]{3}{*}{ TSS } & İstanbul & - & 0.03 & 0.12 & 0.01 & -0.00 & 0.05 & 0.03 & 0.05 & 0.02 \\
\hline & & Çanakkale & -0.00 & - & 0.03 & -0.00 & 0.02 & 0.00 & 0.00 & 0.03 & 0.02 \\
\hline & & Armutlu & 0.00 & 0.01 & - & 0.04 & 0.12 & 0.00 & 0.01 & 0.07 & 0.11 \\
\hline & \multirow{2}{*}{$\begin{array}{c}\text { Aegean } \\
\text { Sea }\end{array}$} & İzmir & 0.00 & -0.13 & 0.00 & - & 0.01 & 0.01 & 0.00 & 0.03 & 0.03 \\
\hline & & Muğla & 0.00 & -0.04 & 0.00 & 0.00 & - & 0.06 & 0.03 & 0.05 & 0.03 \\
\hline & \multirow{2}{*}{$\begin{array}{c}\text { Black } \\
\text { Sea }\end{array}$} & Rize & 0.01 & 0.00 & 0.03 & -0.13 & -0.04 & - & -0.01 & 0.03 & 0.04 \\
\hline & & Sinop & 0.00 & -0.19 & 0.00 & 0.00 & 0.00 & -0.19 & - & 0.02 & 0.03 \\
\hline & \multirow[t]{2}{*}{ Levantine } & Antalya & -0.00 & 0.00 & 0.00 & -0.13 & -0.05 & 0.00 & -0.19 & - & 0.01 \\
\hline & & Mersin & 0.00 & -0.06 & 0.00 & 0.00 & 0.00 & -0.05 & 0.00 & -0.06 & - \\
\hline
\end{tabular}


1014 Table 2. Hierarchical AMOVA results COI+cyt-b (top) and IRBP genes (bottom).

1015 TSS: Turkish Strait System.

\begin{tabular}{|c|c|c|c|c|c|c|}
\hline & $\begin{array}{l}\text { Source of } \\
\text { variation }\end{array}$ & $\begin{array}{l}\text { Total } \\
\text { variation }\end{array}$ & $\begin{array}{l}\text { Percent of } \\
\text { total }\end{array}$ & $\Phi_{C T} / F_{C T}$ & $\Phi_{S C} / F s c$ & $\Phi_{S T} / F_{S T}$ \\
\hline \multirow{4}{*}{$\begin{array}{c}\text { COI } \\
+ \text { cyt-b } \\
\text { genes }\end{array}$} & $\begin{array}{l}\text { Among groups } \\
\text { (TSS, Black Sea, } \\
\text { Aegean Sea and } \\
\text { Levantine) }\end{array}$ & 0.0007 & 2.60 & $\begin{array}{l}0.0260 \\
(\mathrm{p}=0.3142)\end{array}$ & & \multirow{4}{*}{$\begin{array}{l}-0.0213 \\
(p=0.6215)\end{array}$} \\
\hline & $\begin{array}{l}\text { Among } \\
\text { populations } \\
\text { within groups }\end{array}$ & -0.0014 & -4.74 & & $\begin{array}{l}-0.0486 \\
(p=0.7799)\end{array}$ & \\
\hline & $\begin{array}{l}\text { Within } \\
\text { populations }\end{array}$ & 0.0304 & 102.14 & & & \\
\hline & Total & 0.0297 & & & & \\
\hline \multirow{4}{*}{$\begin{array}{l}\text { IRBP } \\
\text { gene }\end{array}$} & $\begin{array}{l}\text { Among groups } \\
\text { (TSS, Black Sea, } \\
\text { Aegean Sea and } \\
\text { Levantine) }\end{array}$ & 0.0041 & 1.31 & $\begin{array}{l}0.0131 \\
(\mathrm{p}=0.1485)\end{array}$ & & \multirow{4}{*}{$\begin{array}{l}0.0367 \\
(p=0.0000)\end{array}$} \\
\hline & $\begin{array}{l}\text { Among } \\
\text { populations } \\
\text { within groups }\end{array}$ & 0.0074 & 2.36 & & $\begin{array}{l}0.0239 \\
(p=0.0000)\end{array}$ & \\
\hline & $\begin{array}{l}\text { Within } \\
\text { populations }\end{array}$ & 0.3038 & 96.33 & & & \\
\hline & Total & 0.3154 & & & & \\
\hline
\end{tabular}


Table 3. Neutrality test results for S. flexuosa /S. maena (including all GenBank individuals); N: Number of the samples; D: Tajima's $D$; Fs: Fu's $F_{\mathrm{S}}$; (2 sequences per individual for IRBP gene). Significant values $(P<0.05)$ are indicated in bold. TSS: Turkish Strait System.

\begin{tabular}{|c|c|c|c|c|}
\hline & Sampling sites & $\mathbf{N}$ & $D$ & $F_{S}$ \\
\hline \multirow{6}{*}{$\begin{array}{l}\text { COI } \\
\text { gene }\end{array}$} & Total S. flexuosa & 196 & -1.6251 & $\begin{array}{l}-7.8670 \\
\end{array}$ \\
\hline & TSS & 58 & - & - \\
\hline & Black Sea & 31 & -1.1447 & -1.2385 \\
\hline & Aegean Sea & 41 & -1.1218 & -1.4706 \\
\hline & Levantine & 45 & -1.1131 & -1.5482 \\
\hline & Total S. maena & 27 & -0.7274 & -1.4952 \\
\hline \multirow{6}{*}{$\begin{array}{l}\text { cyt-b } \\
\text { gene }\end{array}$} & Total S. flexuosa & 143 & -1.6899 & -7.6158 \\
\hline & TSS & 62 & -1.0804 & -1.8164 \\
\hline & Black Sea & 25 & - & - \\
\hline & Aegean Sea & 22 & -1.1624 & -0.9567 \\
\hline & Levantine & 30 & -1.2555 & -1.6685 \\
\hline & Total S. maena & 21 & -1.1635 & -0.9188 \\
\hline \multirow{6}{*}{$\begin{array}{r}\text { IRBP } \\
\text { gene }\end{array}$} & Total S. flexuosa & 348 & -2.2274 & -56.5358 \\
\hline & TSS & 120 & -2.0581 & -15.5390 \\
\hline & Black Sea & 64 & -2.0239 & -13.5505 \\
\hline & Aegean Sea & 76 & -2.1256 & -11.7787 \\
\hline & Levantine & 88 & -1.9022 & -14.8931 \\
\hline & Total S. maena & 43 & -1.3023 & -2.1189 \\
\hline
\end{tabular}


Figure 1. Sampling locations of three Spicara species in this study and GenBank, based on the COI, cyt-b and the IRBP genes, and the taxonomic evaluations from literature [(Spicara smaris L. 1758, Spicara maena L.1758, and Spicara flexuosa (Rafinesque 1810)]. GenBank samples are indicated by the GB suffix. Numbers on the figures indicate sampling locations. Localities information are found in Supporting Information Table S1.

1019

1020

1021

1022

1023

1024

1025

1026

1027

1028

1029

1030

1031

1032

1033

1034

Figure 2. a.) Spicara maena FishTrace specimen SpiMae-EM-04, b) S. flexuosa: FishTrace specimen SpiFle-EM-03, (Photos by Panos Leontarakis/Laurence FavreKrey), c) S. maena collected from Greece, d) S. flexuosa collected from Turkish coastal waters.

Figure 3. Haplotype networks of a) COI, b) cyt-b and c) IRBP genes of Spicara spp. Note: Background of pink color indicates S. flexuosa, blue color indicates S. maena, and white color indicates $S$. smaris. The numbers correspond to number of mutations between haplotypes in A, B and C.

Figure 4. Bayesian topology of the concatenated mtDNA (COI and cyt-b) genes (total $809 \mathrm{bp)}$ of Spicara spp. The numbers on the branches are the Bayesian posterior probabilities. TSS: Turkish Straits System. Hap1: S. smaris GenBank accession no: COI: KT883623, cyt-b: KT883672.

Figure 5. BEAST chronogram based on the concatenated mtDNA (COI and cyt-b) genes of Spicara spp. without outgroup dating. Values above branches are the mean node height (age). Bars show $95 \%$ HPD. Values below branches are posterior probabilities. 
1035 Figure 6. Extended Bayesian Skyline Plots for a) S. flexuosa, b) S. maena, reflecting 1036 changes effective population size against time in years (Ya) before present. CPD 1037 indicates central posterior density interval.

1038

1039

1040

1041

1042 


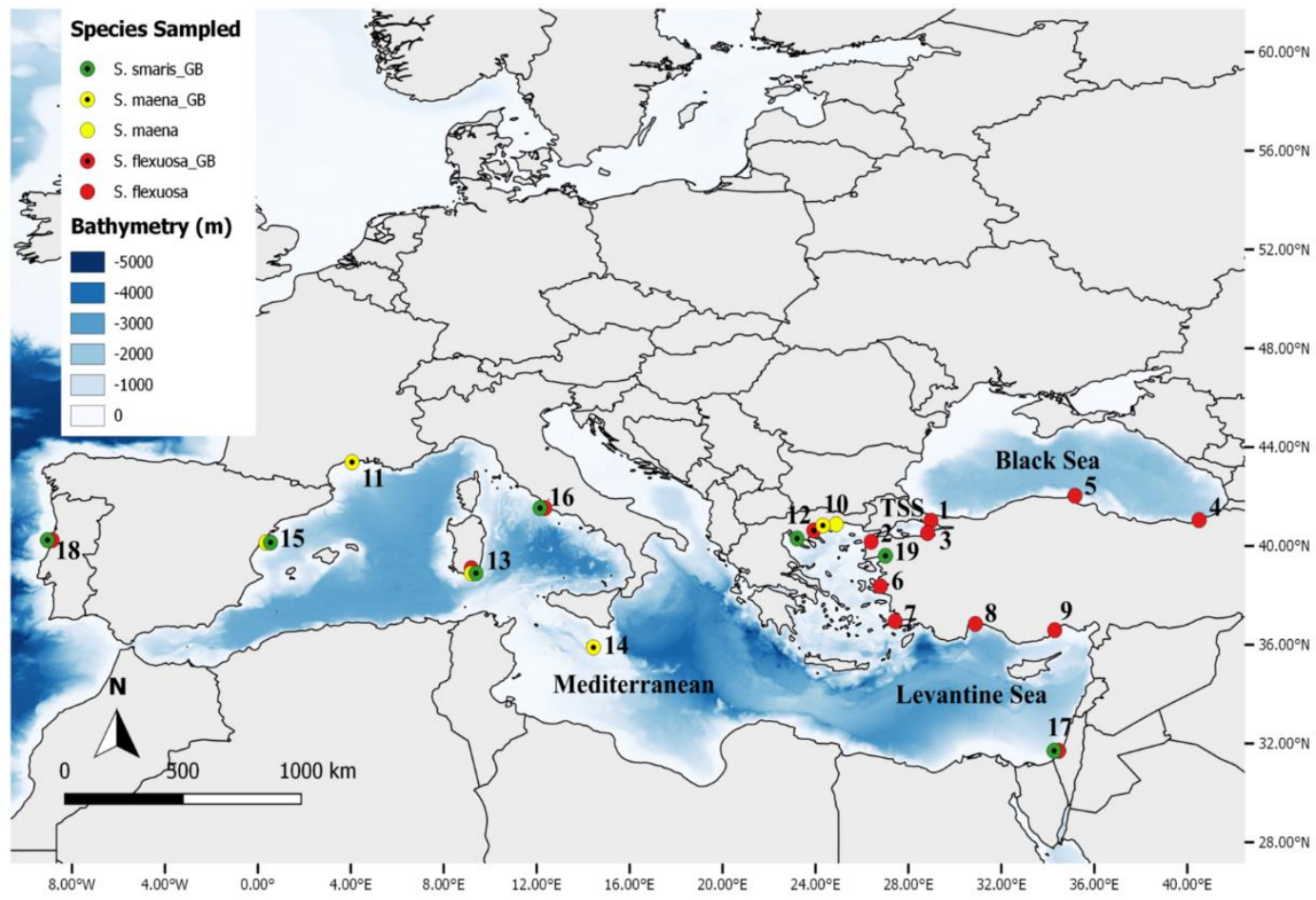

1044

Figure 1.

1045

1046

1047

1048

1049

1050

1051

1052

1053

1054

1055

1056 
a)

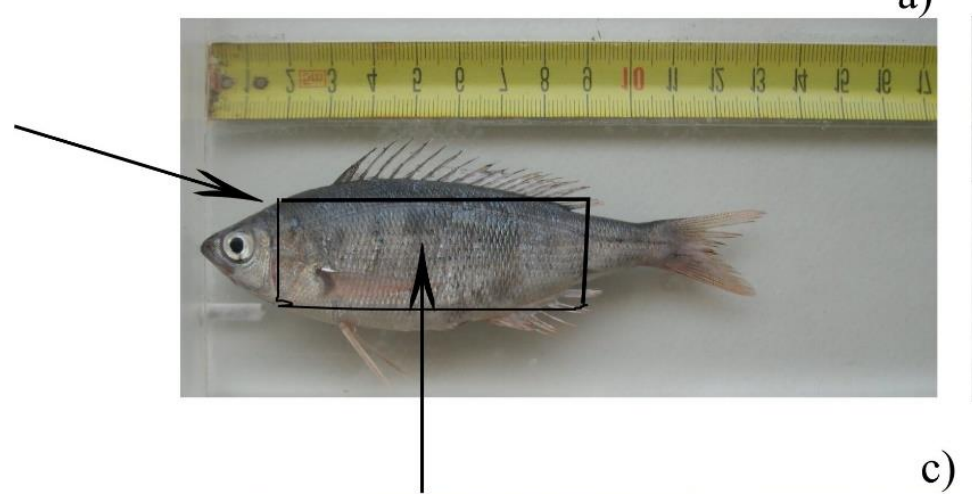

b)

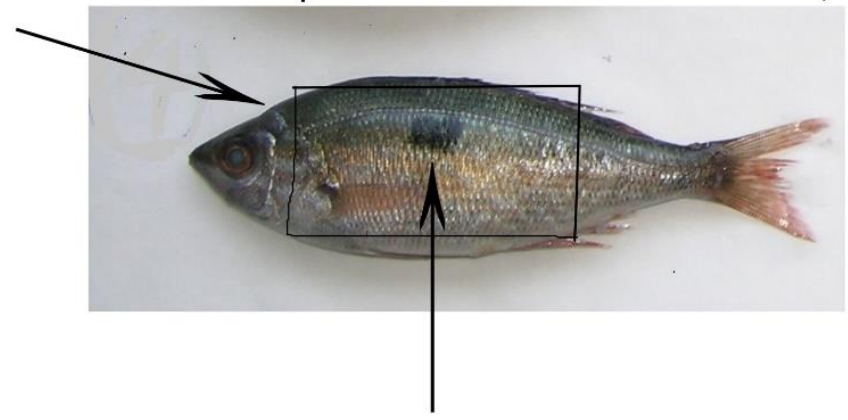

d)

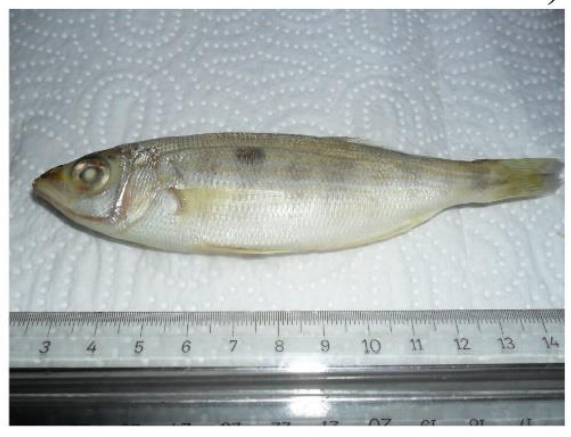

1057 Figure 2.

1058

1059

1060

1061 
1062

1063

1064

1065

1066

1067

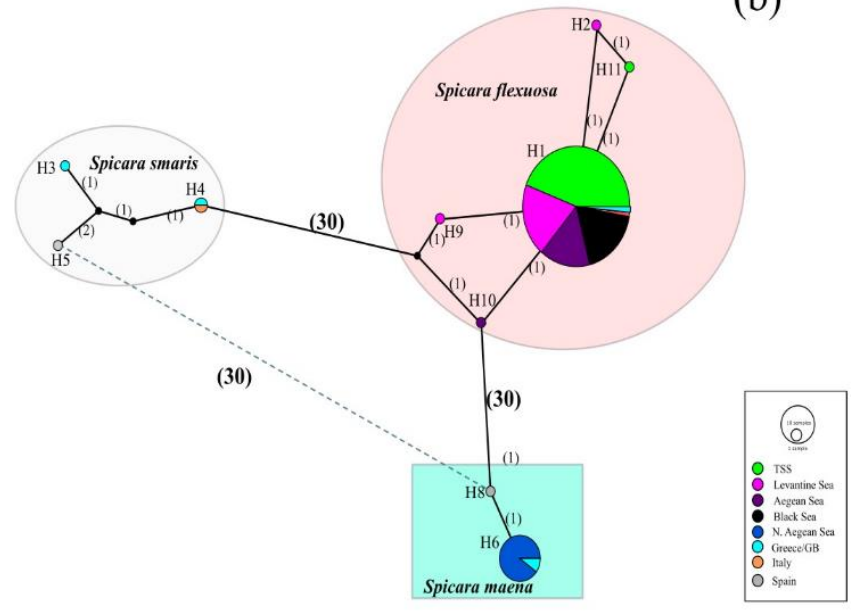

1068

1069

1070

1071

1072

1073

1074

1075

1076

1077 Figure 3. (a)
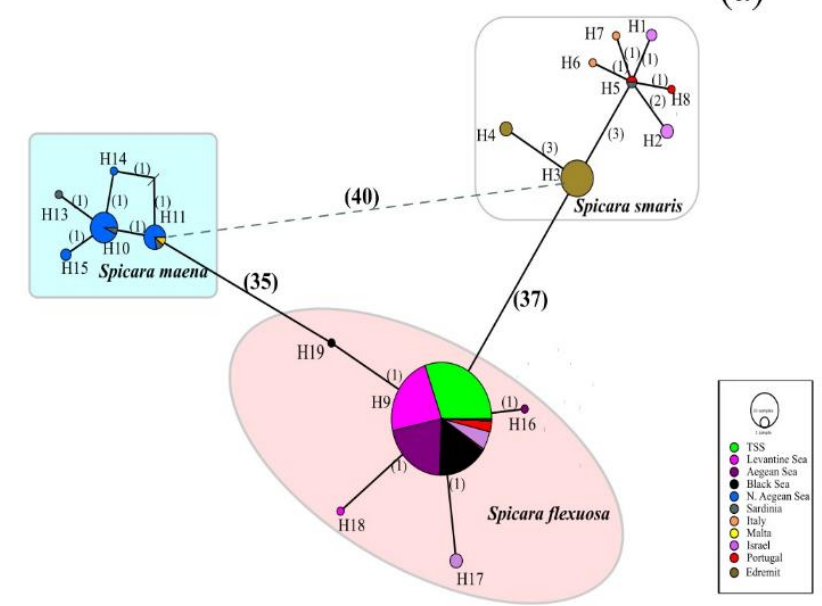

(b) 
1078

1079

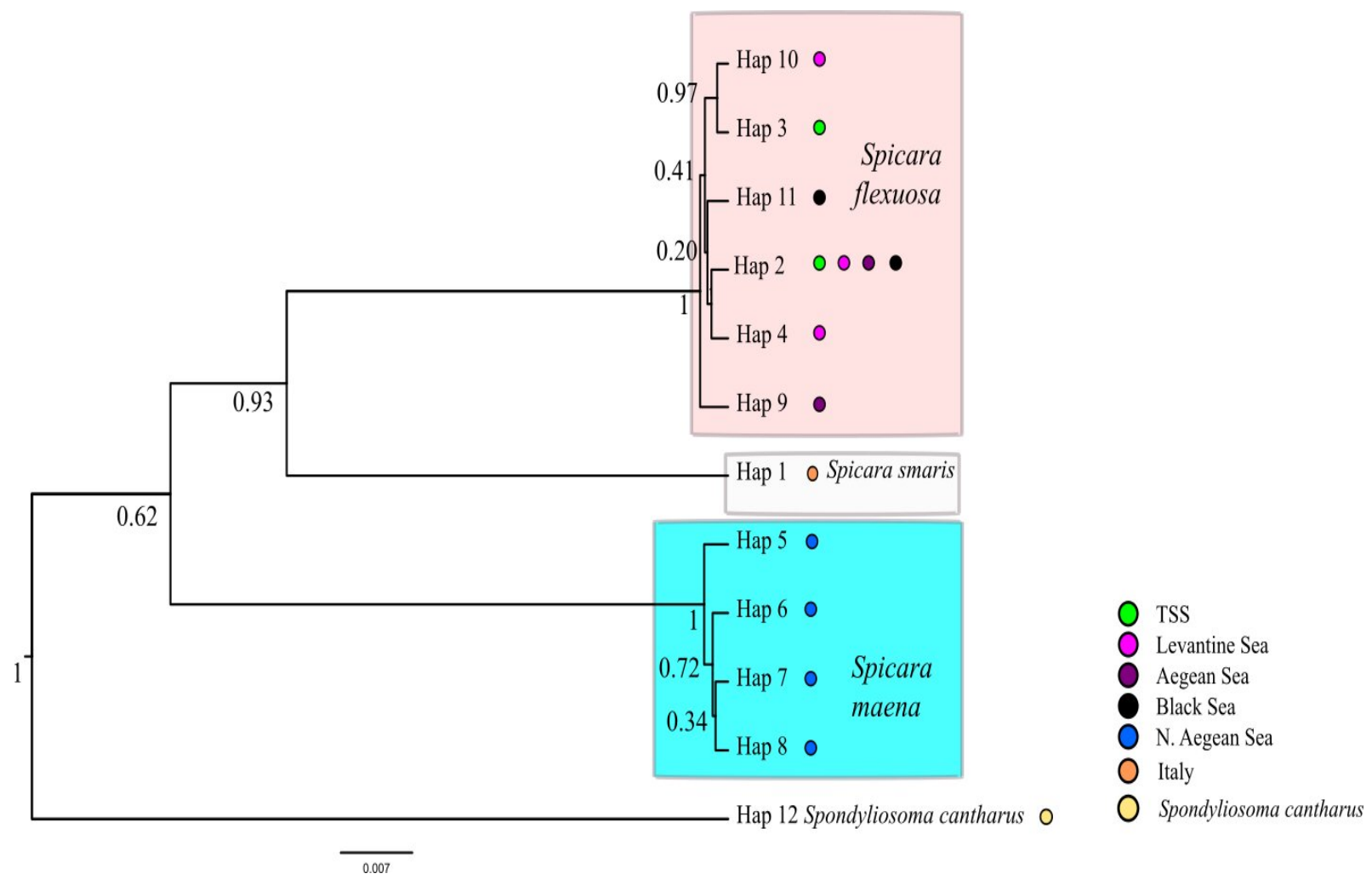

1080 Figure 4.

1081

1082

1083

1084

1085

1086

1087

1088

1089

1090

1091

1092 
1093

1094

1095

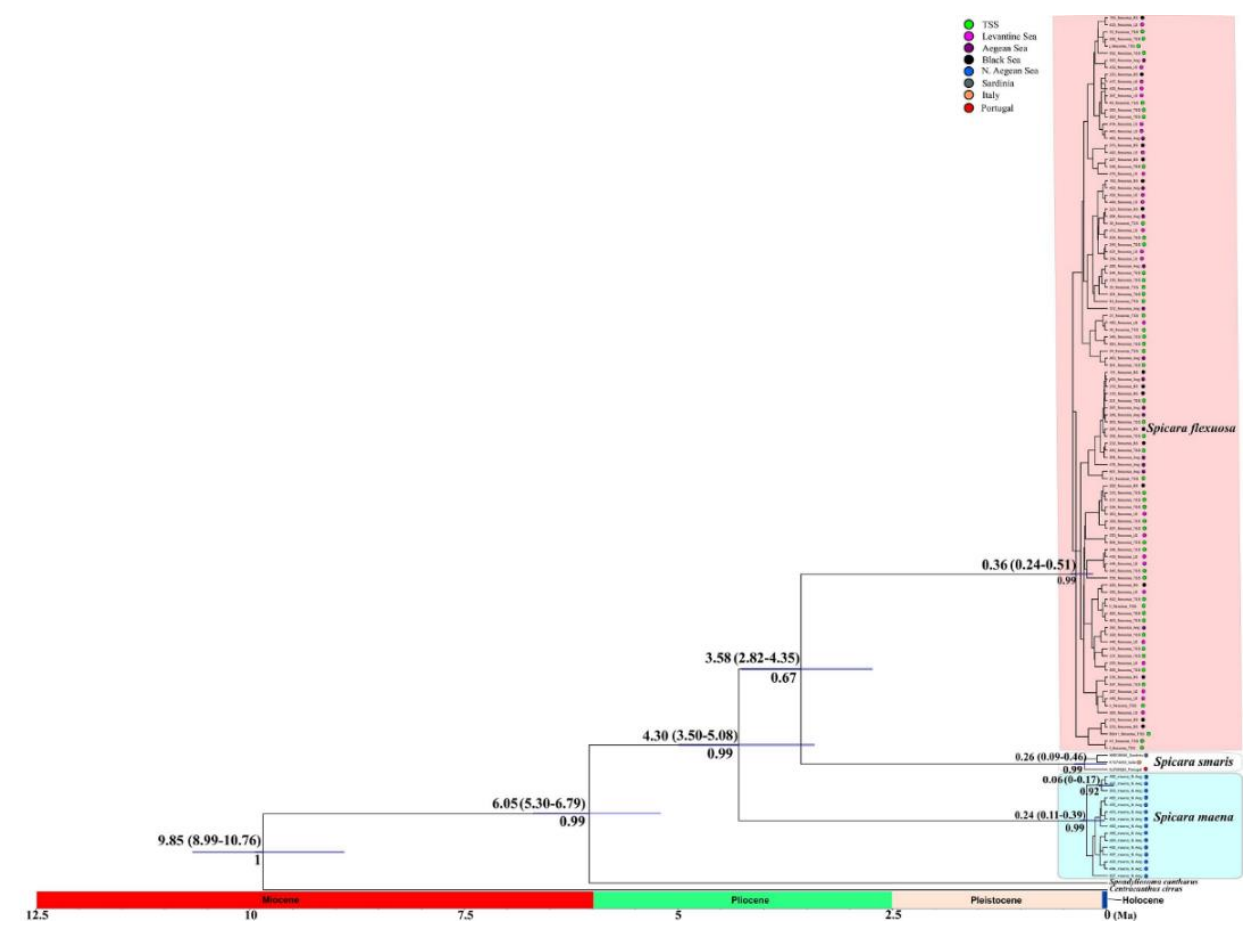

1096 Figure 5.

1097

1098

1099

1100

1101

1102

1103

1104

1105

1106

1107 
1108

1109

(a)

(b)
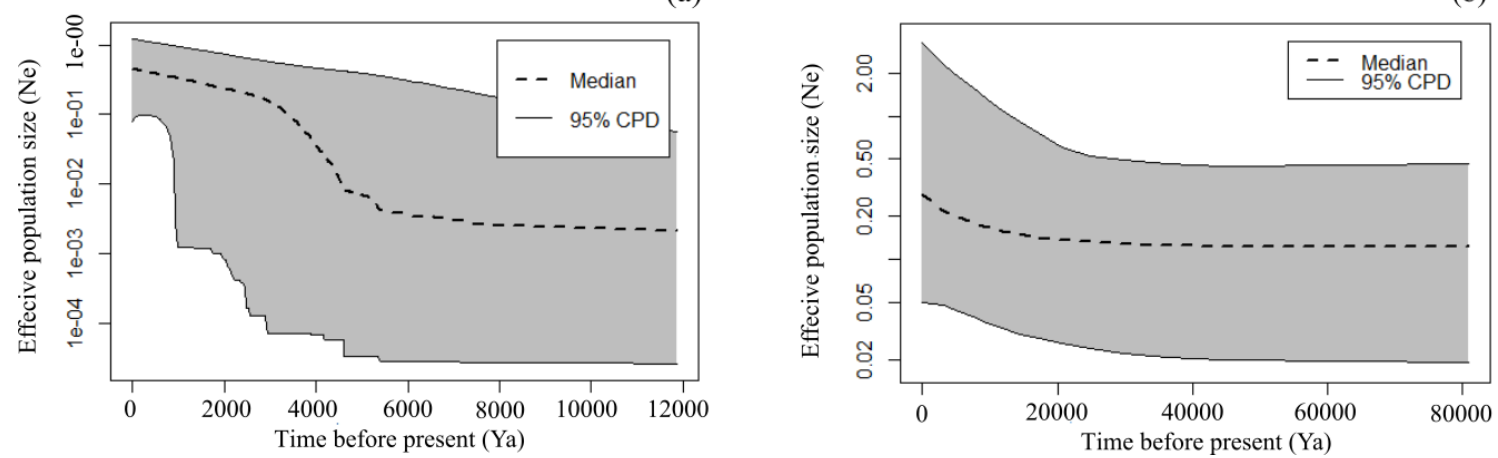

1110 Figure 6.

1111

1112

1113

1114

1115

1116

1117

1118

1119

1120

1121 Figure 6.

1122 